\title{
An Introduction to Audit Studies in the Social Sciences
}

\author{
S. Michael Gaddis \\ mgaddis@soc.ucla.edu \\ Assistant Professor \\ Department of Sociology \\ University of California - Los Angeles
}

January 2018

\section{Pre-Publication Draft: Please see footnote for citation. ${ }^{1}$}

Keywords: audit studies, correspondence audits, discrimination, field experiments

\begin{abstract}
An audit study is a specific type of field experiment primarily used to test for discriminatory behavior when survey and interview questions induce social desirability bas. In this chapter, I first review the language and definitions related to audit studies and encourage adoption of a common language. I then discuss why researchers use the audit method as well as when researchers can and should use this method. Next, I give an overview of the history of audit studies, focusing on major developments and changes in the overall body of work. Finally, I discuss the limitations of correspondence audits and provide some thoughts on future directions.
\end{abstract}

Acknowledgments: Many scholars have played important roles in sharpening my thoughts on this method. I cannot name them all here but I want to express my thanks to Devah Pager, Bill Carbonaro, Joanna Lahey, and David Pedulla for support in helping this volume come together. Additionally, I would like to thank fellow panelists and audience members at sessions on audits at the 2014 annual meeting of the Association for Public Policy Analysis and Management in Albuquerque, NM and the 2015 annual meeting of the American Sociological Association in Chicago, IL.

\footnotetext{
${ }^{1}$ Gaddis, S. Michael. 2018. “An Introduction to Audit Studies in the Social Sciences.” In Audit Studies: Behind the Scenes with Theory, Method, and Nuance, edited by S. M. Gaddis, p3-p44. Cham, Switzerland: Springer International Publishing.
} 


\section{INTRODUCTION}

Since the 1960s, researchers have had a methodological tool at their disposal unlike any other: the audit study. ${ }^{2}$ The audit study is a specific type of field experiment that permits researchers to examine difficult to detect behavior, such as racial and gender discrimination, and decision-making in real-world scenarios. Audit studies allow researchers to make strong causal claims and explore questions that are often difficult or impossible to answer with observational data. This type of field experiment has exploded in popularity in recent years, particularly to examine different types of discrimination, due to the rise of online applications for housing and employment and easy access to decision makers across many contexts via email.

However, the learning curve for designing and implementing these experiments can be quite steep, despite appearing to be a simple and quick method for examining discrimination. Thus, we have written this book to help scholars design, conduct, and analyze their own audits. This book draws upon the knowledge of a variety of social scientists and other experts who combined have implemented dozens of in-person and correspondence audits to examine a variety of research questions. These experienced scholars share insights from both their successes and failures and invite you, the reader, "behind the scenes” to examine how you might construct your own audit study and improve upon this method in the future. We write this book with a wide audience in mind and hope that you will find this book useful whether you have already fielded your own audit study, are just thinking about how you might design an audit study, or just want to learn more about the method to better understand research using audits.

\footnotetext{
2 These types of studies are known by a variety of names, often depending on the decade of publication, the context and method used for testing, discipline, or country. Audits are also sometimes referred to as correspondence tests or situation tests. For now, I refer to all this research as "audit studies.” Later in this chapter, I define and clarify these terms.
} 
In this introductory chapter, I approach the subject as one might with a lay audience. However, even experienced researchers with in-depth knowledge of the audit method should find this chapter useful. I mostly focus on the aspects of audit studies related to research rather than those related to activism or law and policy. ${ }^{3}$ I begin this chapter with the basics - a discussion of the language and definitions related to audit studies. Significant differences in language persist between studies, researchers, and disciplines, and I hope that this section will help readers understand these differences as well as encourage researchers to adopt a common language. Next, I give a succinct overview of why researchers began using audits to examine discrimination. The audit method is a powerful tool to answer certain types of questions and I attempt to outline when researchers can and should use this method. I then give an overview of the history of audit studies. Although others have written superb reviews of this body of literature in the past (Baert this volume; Oh and Yinger 2015; Riach and Rich 2002; Zschirnt and Ruedin 2016), I focus on the forest rather than the trees in this section and provide a narrative of the arc of audit studies over time. ${ }^{4}$ Finally, I close this chapter with a succinct discussion of the limitations of correspondence audits and thoughts on how we might improve this method. This is a not a comprehensive section, but I do think it complements the closing chapter of this book (Pedulla this volume).

Readers looking for additional information on audit studies should consult two resources. First, we have created a website - www.auditstudies.com - to go along with the release of this volume. There you will find a comprehensive database of audits as well as additional

\footnotetext{
${ }^{3}$ For an excellent chapter on the connections to activism, see Cherry and Bendick (this volume) and for an excellent, although a bit outdated, chapter on the links between audits and law and policy, see Fix, Galster, and Struyk 1993.

${ }^{4}$ Some of the work in this section stems from and expands upon work I did to examine the signals of race conveyed by names in correspondence audits (Gaddis 2017a, 2017b, 2017c, forthcoming).
} 
information. Second, at the end of this chapter I provide a brief recommended reading section of important comprehensive works, reviews, and other methods-based articles and books.

Beyond this introductory chapter, several accomplished scholars present their expert knowledge about audit studies. In the first section - The Theory Behind and History of Audit Studies - the authors cover a wide range of history, explain why we should conduct audit studies, examine the connections between audit studies and activism, and outline what researchers have uncovered about labor market processes using audit studies in the past decade. In the second section - The Method of Audit Studies: Design, Implementation, and Analysis - the experts provide guidance on designing your own audit study, discuss the challenges and best practices regarding email, review extensive issues of validity, and consider the technical setup of matching procedures. In the final section - Nuance in Audit Studies: Context, Mechanisms, and the Future - the authors focus on more nuanced aspects of audit studies and address limitations and challenges, examine the use of context to explore mechanisms, and consider the value of variation. I return to a brief discussion of the rest of this book at the end of this chapter.

\section{THE BASICS OF AUDIT STUDIES: LANGUAGE AND DEFINITIONS}

Field experiments encompass a wide range of studies and ideas and describe the highest level of the hierarchy I focus on here. Audit studies are one type of field experiment. At their core, field experiments in the social sciences attempt to mimic the experiments of the natural sciences by implementing a randomized research design in a field setting (as opposed to a lab or survey setting). Although many may think of psychology as the disciplinary home to social science experiments, researchers in economics, political science, and sociology have ramped up the quantity and quality of field experiments conducted in these disciplines over the past few 
decades. Although not the only reason for the increase in field experiments across these disciplines, audit studies do represent a major part of the heightened activity.

Audit studies generally refer to a specific type of field experiment in which a researcher randomizes one or more characteristics about individuals (real or hypothetical) and sends these individuals out into the field to test the effect of those characteristics on some outcome. Historically, audit studies have focused on race and ethnicity (Daniel 1968; Bertrand and Mullainathan 2004; Wienk et al. 1979) and gender (Ayres and Siegelman 1995; Levinson 1975; Neumark, Bank, and Van Nort 1996). In recent years, researchers have expanded the manipulated characteristics to include age (Ahmed, Andersson, and Hammarstedt 2012; Bendick, Jackson, and Romero 1997; Farber, Silverman, and von Wachter 2017; Lahey 2008; Neumark, Burn, and Button 2016; Riach 2015; Riach and Rich 2010), criminal record (Baert and Verhofstadt 2015; Evans 2016; Evans and Porter 2015; Furst and Evans 2016; Pager 2003), disability (Ameri et al. forthcoming; Baert 2014a; Ravaud, Madiot, and Ville 1992; Turner et al. 2005; Verhaeghe, Van der Bracht, and Van de Putte 2016), educational credentials (Carbonaro and Schwarz this volume; Darolia et al. 2015; Deming et al. 2016; Deterding and Pedulla 2016; Gaddis 2015, 2017d; Jackson 2009), immigrant assimilation or generational status (Gell-Redman et al. 2017; Ghoshal and Gaddis 2015; Hanson and Santas 2014), mental health (Baert et al. 2016a), military service (Baert and Balcaen 2013; Figinski 2017; Kleykamp 2009), parental status (Bygren, Erlandsson, and Gähler 2017; Correll, Benard, and Paik 2007; Petit 2007), physical appearance (Bóo, Rossi, and Urzúa 2013; Galarza and Yamada 2014; Maurer-Fazio and Lei 2015; Patacchini, Ragusa, and Zenou 2015; Ruffle and Shtudiner 2015; Stone and Wright 2013), religious affiliation (Adida, Laitin, and Valfort 2010; Pierné 2013; Wallace, Wright, and Hyde 2014; Wright et al. 2013), sexual orientation (Ahmed, Andersson, and Hammarstedt 2013; 
Baert 2014b; Bailey, Wallace, and Wright 2013; Drydakis 2009, 2011a, 2014; Mishel 2016;

Tilcsik 2011; Weichselbaumer 2015), social class (Heylen and Van den Broeck 2016; Rivera and Tilcsik 2016), and spells of unemployment and part-time employment (Birkelund, Heggebø, and Rogstad 2017; Eriksson and Rooth 2014; Kroft, Lange, and Notowidigdo 2013; Pedulla 2016), among other characteristics (Baert and Omey 2015; Drydakis 2010; Kugelmass 2016; Tunstall et al. 2014; Weichselbaumer 2016).

The "individuals" sent into the field may be actual people in an in-person audit or simply applicants or emails from hypothetical people in correspondence audits (more below). The outcomes may be an offer to interview for a job (Bertrand and Mullatinathan 2004; Darolia et al. 2015; Deming et al. 2016; Gaddis 2015), a job offer (Bendick, Jackson, and Reinoso 1994; Bendick, Rodriguez, and Jayaraman 2010; Pager, Western, and Bonikowski 2009; Turner, Fix, and Struyk 1991), the order in which applicants are contacted (Duguet et al. 2015), a response to a housing inquiry (Ahmed and Hammarstedt 2008; Bengtsson, Iverman, and Hinnerich 2012; Carlsson and Eriksson 2014; Carpusor and Loges 2006; Ewens, Tomlin, and Wang 2014; Feldman and Weseley 2013; Hogan and Berry 2011; Van der Bracht, Coenen, and Van de Putte 2015), the types of housing shown (Galster 1990a; Turner et al. 2002, 2013), information about the availability of a house for purchase or rent (Galster 1990b, Turner et al. 2002, 2013; Yinger 1986), an offer of different housing than requested or racial steering (Galster and Godfrey 2005; Turner, Mikelsons and Edwards 1990), a response to a mortgage application or request for information (Hanson et al. 2016; Smith and Cloud 1996; Smith and DeLair 1999), a response to a roommate request (Gaddis and Ghoshal 2015, 2017; Ghoshal and Gaddis 2015), an offer to schedule a doctor's appointment (Kugelmass 2016; Sharma, Mitra, and Stano 2015), a response from a politician or other public official (Broockman 2013; Butler and Broockman 2011; Chen, 
Pan, and Xu 2016; Distelhorst and Hou 2014; Einstein and Glick 2017; Hemker and Rink forthcoming; Janusz and Lajevardi 2016; McClendon 2016; Mendez and Grose 2014; White, Nathan, and Faller 2015), a response from a professor (Milkman, Akinola, and Chugh 2012, 2015; Zhao and Biernat 2017), the price paid or bargained for economic transactions for goods (Anagol, Cole, and Sarkar 2017; Ayres 1991; Ayres and Siegelman 1995; Besbris et al. 2015; Doleac and Stein 2013), or a number of other outcomes (Allred et al. 2017; Edelman, Luca, and Svirsky 2017; Giulietti, Tonin, and Vlassopoulos 2015; Ridley, Bayton, and Outtz 1989; Wallace et al. 2012; Wissoker, Zimmermann, and Galster 1998; Wright et al. 2015).

Two main variations of audits exist: in-person audits and correspondence audits. Inperson audits rely on trained assistants to conduct the experiment. Early audit studies almost exclusively referred to the research subjects posing as legitimate applicants for employment or housing as testers or auditors. This is due, in part, to the fact that the language for such research was adopted from early testing for legal violations for enforcement rather than research purposes (see Boggs, Sellers, and Bendick 1993 and Fix and Turner 1999 for an in-depth discussion of differences between paired testing for enforcement purposes versus research). However, as correspondence audits overtook in-person audits as the norm and real individuals posing as subjects were not required, researchers shifted their language to refer to applicants, candidates, constituents, prospective tenants, etc. In other words, the language should match what the audit context dictates. Although the language identifying testers, auditors, or applicants may vary due to the nature of the study, we recommend that researchers adopt a common language of "inperson audits" to identify field cases using live human beings and "correspondence audits" to identify online, telephone, or by mail audits using hypothetical individuals or recorded messages in the case of some audits by telephone. 
Although most audit studies include paired (or sometimes triplet) testing with comparisons of two (or three) testers or applicants, not all do (for example, see Hipes et al. 2016; Lauster and Easterbrook 2011; Rivera and Tilcsik 2016). Paired testing, also referred to as matched testing, is a design in which the subject or organization being audited (e.g., employer, real estate agent, etc.) receives applications or emails from two or more of testers with different characteristics. Conversely, non-paired testing is a design in which the subject or organization being audited only ever receives a single tester application or email. For example, a paired test design might send both a black couple and a white couple to each real estate agent's office in the sample whereas a non-paired test design would send only one of the two couples (randomly) to each real estate agent's office in the sample. There can be statistical advantages to paired testing, however, in some cases it may be necessary to implement a non-paired test design to reduce suspicion and avoid experiment discovery (Vuolo, Uggen, and Lageson 2016, this volume; Weichselbaumer 2015, 2016).

\section{THE NEED FOR AUDIT STUDIES ${ }^{5}$}

Not coincidentally, the rise of audit studies by researchers corresponds with the public policy of the civil rights era aimed to stop racial discrimination and reduce, if not eliminate, racial inequality. Prior to the 1960s, racial discrimination in the United States occurred openly in public, was relatively common, had minimal stigma attached to it, was shaped by open prejudicial attitudes and beliefs, and arguably was informed by a conscious or active racial prejudice. Individual employers, real estate agents, and landlords could discriminate with impunity and often made public their beliefs and actions. In the United States, the Civil Rights

\footnotetext{
${ }^{5}$ In this section, I discuss audits studies from the perspective of racial discrimination. However, the need for and use of audits is similar across other types of discrimination as well as some non-discrimination-based domains of inquiry.
} 
Act of 1964 intended to change these behaviors, if not beliefs and attitudes, by outlawing discrimination on the basis of race, color, religion, sex, or national origin. The Equal Employment Opportunity Commission (EEOC) gained the ability to litigate discrimination cases following the passage of the Equal Employment Opportunity Act in 1972. Title VII of the Civil Rights Act of 1964 finally could be enforced.

However, we can imagine and, indeed do live in, a world where the Civil Rights Act may have changed the act of discrimination without changing the amount of discrimination, intentions behind discrimination, or desire to discriminate. Although not a sharp change overnight, discrimination of all types has changed in response to the Civil Rights Act. Modern discrimination has become more covert, uncommon, and stigmatized, while being shaped by private prejudicial attitudes and beliefs, and, perhaps, informed by an unconscious or latent racial prejudice. Individuals may fear litigation for engaging in discrimination or have a social desirability bias to not acknowledge discriminatory actions. This makes it difficult for researchers to document and examine discrimination.

Thus, two traditional methods of social science inquiry are difficult, if not impossible, to employ to examine discrimination in the post-civil rights era. First, pointed interviews and survey questions asking perpetrators about racial discrimination are unlikely to elicit truthful responses. To my knowledge, the most recent research project to successfully elicit clearly truthful responses from employers about engaging in racial discrimination occurred in the late 1980s (Kirschenman and Neckerman 1991). Moreover, surveys and interviews do not document actions, but rather self-reported beliefs, attitudes, recollections of past actions, or predictions of future actions. Due to respondents’ fear and social desirability bias, and the sometimes 
unconscious nature of racial prejudice, direct questions about discrimination through interviews and surveys exhibit low construct validity.

Second, statistical analyses using secondary data that do not have explicit questions about discrimination also fail to adequately capture discrimination. To understand the difficulty of this process, let's first consider a definition of discrimination. In a 2004 book stemming from the Committee on National Statistics' Panel on Methods for Assessing Discrimination, panelists defined racial discrimination as "differential treatment on the basis of race that disadvantages a racial group” (Blank et al. 2004: 39). Although researchers can document the second (race) and third parts (disadvantage) of the definition with secondary data, directly capturing the first part (differential treatment) is impossible. Thus, secondary data analysis must use indirect residual attribution to suggest that, after including a litany of control variables that affect the dependent variable of interest on which blacks and whites differ, any remaining coefficient for race represents discrimination (Blank et al. 2004; Lucas 2008; Neumark forthcoming). However, this method is unlikely to correctly attribute the true amount of racial discrimination (Quillian 2006), due to omitted variable bias, among other issues (Altonji and Blank 1999; Blank et al. 2004; Farkas and Vicknair 1996; Lucas 2008).

Researchers developed the audit method as a means of catching individuals and organizations in the act of discrimination. Generally, experiments can be done when a presumed cause is manipulable and should be done when it is otherwise difficult to prove nonspuriousness. Many, if not all, types of discrimination are great candidates for examination through experimental means because the presumed cause often is manipulable in many contexts and, as discussed earlier, traditional methods of social science inquiry have been unable to directly document discrimination or rule out a spurious relationship. If we consider the 
previously stated definition of racial discrimination - "differential treatment on the basis of race that disadvantages a racial group” (Blank et al. 2004: 39) - we see that audit studies manipulate the second part (race) to directly capture the first part (differential treatment) of the definition. Thus, by carefully controlling and counterbalancing all other variables in the experimental process, audit studies provide strong causal evidence of discrimination.

\section{A HISTORY OF AUDIT STUDIES}

\section{The Early Years: The First In-Person and Correspondence Audits}

In-person audits began in the 1940s and 1950s by means of activists and private organizations with some assistance from academic researchers. One of the earliest media mentions of audits occurred in the New York Times in 1956 (Rowland). In Chapter 2, Frances Cherry and Marc Bendick Jr. (this volume) do an excellent job of covering some of this early work, so I leave discussion of that part of the history of audit studies to them.

The earliest known published audit study of significant scope and scale was conducted in England in the late 1960s. With the Race Relations Acts of 1965, Parliament passed the first legislation addressing racial discrimination in the United Kingdom in public domains. The following year, the U.K. Parliament created the Race Relations Board, which was tasked with reviewing complaints falling under the Race Relations Act. However, the Race Relations Act did not cover employment and housing discrimination until 1968, so in tandem with the National Committee for Commonwealth Immigrants, the Race Relations Board commissioned a study on racial discrimination in employment, housing, and other contexts. Along with surveys and interviews, the study implemented the audit method to extensively examine discrimination (Daniel 1968). 
Described as "situation tests," the audits were born when Daniel and the research team had doubts over whether surveys and interviews would give them an accurate portrayal of the state of discrimination. Moreover, the team was unsure if the "findings would appear conclusive to those people who are strongly passionate or committed about the subject on one side or the other" (1968: 20). That doubt led them "not to depend entirely on what people told us in interviews, but to put the matter to the test in a way that would provide objective evidence" (ibid). These tests were conducted with triplets of candidates - usually white English, white immigrant, and black applicants - in the domains of housing (both rental and purchase), employment, and other services. The tests consistently uncovered discrimination against blacks and immigrants.

At the time, this commissioned study of racial discrimination was monumentally important. Along with the hard work of researcher William Wentworth Daniel, results from this study led to the revised Race Relations Act of 1968 outlawing racial discrimination in employment and housing (Smith 2015). However, this study often has been overlooked or forgotten by academics; at the time of this writing, Google Scholar reports that the resulting book by Daniel (1968) has garnered fewer than 500 citations in nearly fifty years. Still, Racial Discrimination in England's use of the audit method in government-sponsored research marks the beginning of a series of high profile in-person audits conducted to examine racial discrimination.

Just a few years later, in 1969, the first-ever correspondence audit was conducted in the United Kingdom. Published by two researchers from the non-profit institute Social and Community Planning Research, this study sought to examine racial discrimination among employers looking to hire white-collar workers (Jowell and Prescott-Clarke 1970). The authors 
chose to conduct a correspondence audit through the mail because "postal applications were possible and, in many cases, necessary” to apply for employment (1970: 399). The authors matched British-born whites with four different immigrant groups to test for racial discrimination across an ambitious-for-the-time 128 job postings (256 total applicants) and noted the importance of both realism in the application and controlling for all differences between candidates including aspects such as handwriting. Again, although this study has collected few citations in nearly fifty years (fewer than 150 at the time of this writing), it remains an incredibly important entry in the annals of the audit method because it introduced the world to correspondence audits.

\section{The First Wave: The Early 1970s through the Mid 1980s}

In the United States, a number of non-academic-based audits followed the two UK studies. Private fair housing audits rose to prominence in the late 1960s and 1970s in the United States following passage of the Civil Rights Act of 1968 (also known as the Fair Housing Act), which provided federal enforcement of anti-discrimination housing law through an office of the U.S. Department of Housing and Urban Development (HUD). These audits were often conducted in partnership with academic researchers (often local) and often focused on one major city, such as Akron, Ohio (Saltman 1975), Chicago (as reported in Cohen and Taylor 2000), Detroit (Pearce 1979), Los Angeles (Johnson, Porter, and Mateljan 1971), and New York (as reported in Purnell 2013). Additionally, organizations often produced method-based manuals and guides for the practice of auditing (Kovar 1974; Leadership Council for Metropolitan Open Communities 1975; Murphy 1972). 
However, the largest, and arguably most important, audit on housing discrimination during this era, the Housing Market Practices Survey (HMPS), occurred in 1977 (Wienk et al. 1979). This first large-scale housing audit was commissioned by HUD to test for discrimination against blacks in both the sale and rental housing markets. HUD paired with local fair housing organizations and other organizations to recruit and train testers to conduct the in-person audits. This research included 3,264 audits across forty metro areas, with a plurality of the audits occurring in five metro areas. The HMPS found discrimination against blacks in reported housing availability, treatment by real estate agents, reported terms and conditions, and the types and levels of information requested by real estate agents. This research was critically important in leading the way for future audits, including three additional national housing audits commissioned by HUD (Turner and James 2015; Turner et al. 2002, 2013; Turner, Struyk, and Yinger 1991; Yinger 1991, 1993), several smaller local audits (see below), and the Urban Institute employment audits a decade later (Cross et al. 1990; Mincy 1993; Turner, Fix, and Struyk 1991). Arguably, four aspects of the HMPS were important in shaping future audits. First, the HMPS showed that large-scale audits for discrimination in the United States were possible. Second, this research essentially gave auditing a gold seal of approval from an arm of the federal government (for more details on audits and the courts, see Boggs, Sellers, and Bendick 1993; Fix, Galster, and Struyk 1993; and Pager 2007a). Third, it was the first research to show the extent to which racial discrimination was widespread. Finally, the HMPS showed creativity in expanding the outcomes examined by audits.

Other one-off in-person and correspondence audits conducted during the 1970s and early 1980s examined housing and employment discrimination in the United Kingdom (McIntosh and Smith 1974), housing discrimination in France (Bovenkerk et al. 1979) and the United States 
(Feins and Bratt 1983; Galster and Constantine 1991후 Hansen and James 1987; James, McCummings, and Tynan 1984; Newburger 1984; Roychoudhury and Goodman 1992, 19967), and employment discrimination in the United States (Hitt, Zikmund, and Pickens 1982; Jolson 1974; Levinson 1975; McIntyre, Moberg, and Posner 1980; Newman 1978), Canada (Adam 1981; Henry and Ginzberg 1985), Australia (Riach and Rich 1987, 1991), and England (Brown and Gay 1985; Firth 1981; Hubbuck and Carter 1980). George Galster (1990a, 1990b) reviewed several fair housing audits conducted in the 1980s that were mostly unpublished and analyzed data from seventy-one separate audits.

During this period, researchers also began to expand the domains in which they investigated discrimination. As early as 1985, Galster and Constantine (1991) investigated housing discrimination based on parental and relationship status among women. Ayres (1991 and Ayres and Siegelman 1995) examined racial and gender discrimination in bargaining for new car prices, while Ridley Bayton and Outtz (1989) examined racial discrimination in hailing a taxi. Other research from this period examined discrimination based on disability (Fry 1986; Graham, Jordan, and Lamb 1990; Ravaud, Madiot, and Ville 1992). The first wave of audits conducted in the 1970s and 1980s filled in a number of gaps in our knowledge about the extent and geography of discrimination, conditions under which discrimination occurred, and variations in outcomes that were affected by discrimination, particularly in housing and, to some degree, employment.

\section{The Second Wave: The Late 1980s through the Late 1990s}

Beginning with the last part of the 1980s and continuing throughout the 1990s, a second wave of audits was ushered in with the second iteration of the HUD housing audit (Turner,

${ }^{6}$ Conducted in 1985

${ }^{7}$ Conducted throughout the 1980s. 
Micklensons, and Edwards 1991; Yinger 1991, 1995) and a series of large-scale employment audits conducted by the Urban Institute (Cross et al. 1990; Mincy 1993; Turner, Fix, and Struyk 1991), in part, aided by guidelines for adapting housing audits to hiring situations (Bendick 1989). The HUD housing audit in 1989, known as the Housing Discrimination Study (HDS) 1989, was conducted in partnership with the Urban Institute. The HDS 1989 varied from and improved on the HMPS in 1977 in many ways. First, the former included Hispanic testers paired with whites for some audits to examine discrimination against Hispanics as well (Ondrich, Stricker, and Yinger 1998; Page 1995), something that was only done in an extension of the HMPS and only in Dallas (Hakken 1979). Second, in the HDS 1989 auditors focused on specific advertised housing units, whereas in the HMPS auditors approached agents about more general housing options fitting certain criteria. Thus, the HDS 1989 could more accurately examine racial steering. Third, the HDS 1989 examined fewer metro areas (25 instead of 40), but conducted more audits (3,800 instead of 3,264). Overall, the HDS 1989 replicated the general finding of the HMPS that housing discrimination against blacks was prevalent and widespread. However, there was no strong evidence suggesting that discrimination increased or decreased between the two data collection periods (Elmi and Mikelsons 1991).

The first of the Urban Institute employment audits was conducted in Chicago and San Diego in 1989 and examined discrimination against Hispanics (Cross et al. 1990). Researchers sampled newspaper advertisements and matched pairs successfully applied to almost 300 entrylevel jobs in the two cities. The study found that Hispanics faced discrimination at both the application and interview phases, which lead to fewer interviews and fewer job offers when compared with their white counterparts. In 1990, the Urban Institute conducted a similar employment audit in Chicago and Washington, D.C. to examine discrimination against African 
Americans (Turner, Fix, and Struyk 1991). Matched pairs successfully completed nearly 450 audits in the two cities. The study found that employers discriminated against blacks in accepting their applications, inviting them to interview, and offering them a job. Black applicants were also more likely to be steered toward lower quality jobs rather than the advertised position to which they responded. Additionally, whites were treated more favorably in a number of respects, including waiting time, length of interview, and positive comments.

The Urban Institute studies were the first large-scale true employment audits conducted in the U.S. Researchers and staff went to great lengths to make the study as methodologically sound as possible and paid close attention to detail in sampling, creating matched pairs, and standardizing procedures for the audits (Mincy 1993). Although these studies provided a meticulous model for subsequent researchers to follow when conducting employment audits, others have extensively critiqued the Urban Institutes studies and the in-person audit method more broadly (Heckman 1998; Heckman and Siegelman 1993). However, by moving development and knowledge of the method forward and by providing extensive guidance (along with Bendick 1989) for the numerous employment audits that followed them, the Urban Institute audits were clearly of great importance.

Following the HDS 1989 and the Urban Institute employment audits, a wave of audits examining employment, housing, and other forms of discrimination occurred. Many audits were conducted in Europe through the International Labour Office (ILO) based on guidelines developed by Frank Bovenkerk (1992). Studies in the U.S. (Bendick et al. 1991; Bendick, Jackson, and Reinoso 1994; James and DelCastillo 1992; Nunes and Seligman 1999) and Europe (Arrijn, Feld, and Nayer 1998; Bovenkerk et al. 1995; de Prara et al. 1996; Esmail and Everington 1993, 1997; Goldberg, Mourinho, and Kulke 1995; Smeesters and Nayer 1998) 
focused on race and ethnic discrimination. Researchers conducted sex discrimination

employment audits in the U.S. (Neumark, Bank, and Van Nort 1996; Nunes and Seligman 2000) and Europe (Weichselbaumer 2000), as well as age and disability-based discrimination employment audits in the U.S. (Bendick, Brown, and Wall 1999) and Europe (Graham, Jordan, and Lamb 1990; Gras et al. 1996). This period also included the return of telephone-based (Bendick, Brown, and Wall 1999; Massey and Lundy 2001; Purnell, Idsardi, and Baugh 1999) and written correspondence audits (Bendick, Jackson, and Romero 1997; Gras et al. 1996; Weichselbaumer 2000). Still, the cost-prohibitive nature of in-person audits and labor-intensive nature of correspondence audits during the 1990s meant that use of the audit method was relatively rare.

\section{The Third Wave: The Early 2000s through the Late 2000s}

Until the early 2000s, most audits were conducted in-person and relied on trained assistants to physically participate in the process. With housing and employment applications increasingly taking place over the internet, researchers began conducting more correspondence audits. However, some important audits in the early 2000s were still in-person, including the second iteration of HUD and the Urban Institute’s Housing Discrimination Study (HDS 2000: Bavan 2007; Ross and Turner 2005; Turner et al. 2002). Devah Pager was the first to examine the effects of a criminal record using an audit study (2003) and produced an incredibly strong body of work during this period consisting of in-person audits as well as examinations of the method (Pager 2007a, 2007b; Pager, Western, and Bonikowski 2009; Pager and Quillian 2005; Pager and Shepherd 2008; Pager, Western, and Sugie 2009). 
The 2000s brought about significant changes in the audit method and the importance of this era is highlighted by the fact that the two most cited audit studies of all time both occurred in the early 2000s. Devah Pager’s (2003) in-person audit study of race and criminal record in the low-wage labor market in Milwaukee has garnered nearly 1,900 citations according to Google Scholar. Marianne Bertrand and Sendhil Mullainathan's (2004) correspondence audit study of race in labor markets in Boston and Chicago has nearly 3,000 citations at the time of this writing. Both studies have been incredibly important in shaping our understanding of racial discrimination, however, the differences between them are stark and mark a major turning point in audit studies.

Bertrand and Mullainathan’s 2004 study, published in The American Economic Review, is the most influential correspondence audit study of the past two decades. In total, the authors applied to over 1,300 job advertisements, compared to Pager's 350 jobs (2003), listed in newspapers in Boston and Chicago via fax and mail. Additionally, the authors used birth record data and a small convenience sample pretest to select names to convey race on each resume. Rather than send two applicants per job, the authors often used four resumes to examine both race and resume quality simultaneously and obtained a final sample size of 4,870. Bertrand and Mullainathan found that white applicants were about 50\% more likely than black applicants to receive a callback. Moreover, black applicants benefited less than white applicants from higher resume quality.

Bertrand and Mullainathan's (2004) landmark study ushered in a new era of correspondence audits. Arguably, this study paved the way for the increase in audits that followed for at least three reasons. First, the research showed that a large-scale audit - in particular, a correspondence audit - could be undertaken by a small team of academic 
researchers, compared to past audits conducted by larger teams such as those at HUD and the Urban Institute. Although Bertrand and Mullainathan applied via fax and mail, the timing was ripe for the switch to applications over the internet which further expanded the possibilities of correspondence audits. Second, the study opened a dialogue about signaling race through correspondence audits. Because the authors conducted a small pretest and used a moderate number of names - 36 in total - the plurality of studies that followed used the same names to signal race (see Gaddis 2017c). ${ }^{8}$ Although over a decade would pass before scholars began to seriously question these signals (Butler and Homola 2017; Gaddis 2017a, 2017b, 2017c, forthcoming; Weichselbaumer 2017), Bertrand and Mullainathan were the first to truly investigate them. Finally, this study showed that it was possible to successfully manipulate several characteristics simultaneously. Beyond race and gender, the authors varied other resume characteristics such as education, experience, and skills. These manipulations likely sparked ideas among researchers about mechanisms and interactions that would follow in future studies. The vast majority of the studies that followed Bertrand and Mullainathan during the 2000s were conducted via the correspondence method. A few notable exceptions are the previously mentioned studies by Devah Pager (2003; Pager, Western, and Bonikowski 2009) and three studies carried out by the International Labour Office (ILO) in Italy (Allasino et al. 2004), Sweden (Attström 2007), and France (Cediey and Foroni 2008), although the ILO studies used a mix of in-person and correspondence methods. Additionally, two in-person studies examined discrimination in market transactions: baseball card sales (List 2004) and auto repair quotes (Gneezy and List 2004).

\footnotetext{
${ }^{8}$ Although credit should also be given to Lodder, McFarland, and White (2003) who pre-tested names in a small employment correspondence audit in Chicago before Bertrand and Mullainathan (2004).
} 
During this time, correspondence audits examining employment discrimination based on race and ethnicity expanded to cover more countries and race/ethnicities such as Albanians in Greece (Drydakis and Vlassis 2010) and Turks in Germany (Kaas and Manger 2012), and a variety of other groups in Australia (Booth, Leigh, and Varganova 2012), Canada (Oreopoulos 2011), Denmark (Hjarnø and Jensen 2008), France (Duguet et al. 2010), Great Britain (Wood et al. 2009), Ireland (McGinnity and Lunn 2011), Sweden (Bursell 2007; Carlsson 2010; Carlsson and Rooth 2007; Rooth 2010), and the U.S. (Jacquemet and Yannelis 2012; Thanasombat and Trasviña 2005; Widner and Chicoine 2011). Additionally, researchers examined employment discrimination on the basis of gender and family status in France (Petit 2007) and the U.S. (Correll, Benard, and Paik 2007), gender in England (Riach and Rich 2006a), Spain (Albert, Escot, and Fernandez-Cornejo 2011) and Sweden (Arai, Bursell, and Nekby 2016) ${ }^{9}$, age in England (Riach and Rich 2010), France (Riach and Rich 2006b), Spain (Albert, Escot, and Fernandez-Cornejo 2011; Riach and Rich 2007), and the U.S. (Lahey 2008), sexual orientation in Austria (Weichselbaumer 2003), Greece (Drydakis 2009, 2011a) and the U.S. (Tilcsik 20011), race and criminal record in the U.S. (Galgano 2009), race and military status in the U.S. (Kleykamp 2009), educational credentials in the United Kingdom (Jackson 2009), caste in India (Siddique 2011), caste and religion in India (Banerjee et al. 2009), and physical attractiveness and obesity in Sweden (Rooth 2009). One additional study of note during this period is Philip Oreopoulos' correspondence audit in Toronto, which included six different racial/ethnic/immigrant groups. He applied to over 3,200 job postings using 13,000 different resumes to create one of the most ambitious correspondence audits of its time.

The expansion of audit research during the 2000s included housing discrimination studies as well. The HDS 2000 expanded to include Asians and Pacific Islanders as well as Native

\footnotetext{
${ }^{9}$ Conducted in 2006 and 2007.
} 
Americans (Turner and Ross 2003a, 2003b) and examined housing discrimination on the basis of disability (Turner et al. 2005). Correspondence audits examined housing discrimination based on race and ethnicity in Canada (Hogan and Berry 2011), Greece (Drydakis 2011b), Italy (Baldini and Federici 2011), Spain (Bosch, Carnero and Farré 2010), Sweden (Ahmed, Andersson and Hammarstedt 2010; Ahmed and Hammarstedt 2008), and the United States (Carpussor and Loges 2006; Friedman, Squires, and Galvan 2010; Hanson and Hawley 2011; Hanson, Hawley, and Taylor 2011). Additional research examined housing discrimination on the basis of sexual orientation (Ahmed, Andersson and Hammarstedt 2008; Ahmed and Hammarstedt 2009).

Beyond the major expansion of correspondence audits during this time, the period is marked by the beginning of researchers' exploration of mechanisms of discrimination, intentions behind discrimination, and conditions under which discrimination occurs rather than simply documenting the existence of discrimination. At least four studies during this period attempted to uncover greater detail related to these issues. First, two studies followed up with employers after submitting them to an audit to examine bias in more detail. In one study, Devah Pager and Lincoln Quillian (2005) conducted a telephone survey to follow up with employers who had unknowingly participated months earlier in an in-person audit study. When given a vignette scenario that mimicked the audit scenario they were subjected to, employers suggested they would be much more likely to hire individuals than the callback rates suggested. In fact, the results of the vignette survey showed no differences between white and black applicants, suggesting the existence of social desirability bias. In another study, Dan-Olof Rooth (2010) administered the Implicit Association Test (IAT) to test whether discriminatory behavior in a prior correspondence audit was associated with IAT scores. He found a strong positive 
correlation between discrimination against Arab-Muslims ${ }^{10}$ and IAT scores but no correlation with a separate explicit measure of bias. These results could suggest that individuals are engaging in discrimination only due to implicit bias (without having a true explicit bias) or could suggest the existence of social desirability bias.

The second set of studies attempted to distinguish between statistical discrimination and taste-based discrimination. In one study, Joanna Lahey (2008) designed a computerized method of creating resumes to examine many values of many variables rather than the often-binary choice sets of resumes prior to her study (see also Lahey and Beasley 2009). Using this revision of the correspondence audit, she could test if employers were less likely to call back older workers due to judgments and assumptions about human capital (statistical discrimination) or due to a general preference for younger workers (taste-based discrimination). She found some evidence for statistical but not taste-based age discrimination. Importantly, her computerized method of creating resumes has also been used to develop several large-scale correspondence audits (e.g., Deming et al. 2016; Oreopoulos 2011). In another study, Leo Kaas and Christian Manger (2012) conducted a correspondence audit in Germany in which they found that Turkish applicants were less likely to receive a callback than German applicants. However, they submitted some applications with two reference letters that included information on personality and work ethic. The authors found that among applications that included these reference letters, there were no statistical differences between the callback rates for German and Turkish applicants, suggesting that employers in Germany engage in statistical discrimination against Turkish applicants. These four studies highlight an important shift in audit studies from simply documenting discrimination to exploring the process in more detail. This trend would continue throughout the following decade and shape the focus and contributions of future audit studies.

\footnotetext{
${ }^{10}$ Rooth makes a distinction that he is specifically testing the combined category.
} 


\section{The Current Wave: The Early 2010s to Present}

Since the early 2010s, the number of audit studies appearing in journals and working paper form has grown exponentially. By my count, the number of audit studies conducted between 2010 and 2017 is already quadruple the number conducted between 2000 and 2009. For that reason alone, it would be incredibly difficult to cover all of these studies with any detail in this section. With apologies to those not covered here, I focus on what I consider to be the most significant developments during the past seven years. However, it is also important to note that researchers have continued to expand the domains of study to areas such as healthcare (Kugelmass 2016; Sharma, Mitra, and Stano 2015; Shin et al. 2016), politics and public service (Butler and Broockman 2011; Einstein and Glick 2017; Giulietti, Tonin, and Vlassopoulos 2015; Hughes et al. 2017; McClendon 2016; White, Nathan, and Faller 2015), religious organizations (Wallace et al. 2012; Wright et al. 2015), eBay and Craigslist transactions (Besbris et al. 2015; Doleac and Stein 2013; Nunley, Owens, and Howard 2011), and new sharing economy market transactions such as Airbnb and Uber (Cui, Li, and Zhang 2017; Edelman, Luca, and Svirsky 2017; Ge et al. 2016). Additionally, researchers have expanded the countries of study to include Argentina (Bóo, Rossi, and Urzúa 2013), Belgium (Baert 2016; Baert and Verhofstadt 2015), Brazil (de Leon and Kim 2016), China (Maurer-Fazio 2012; Maurer-Fazio and Lei 2015; Zhou, Zhang, and Song 2013), the Czech Republic (Bartoš et al. 2016), Ghana (Michelitch 2015), Israel (Ariel et al. 2015; Ruffle and Shtudiner 2015; Zussman 2013), Malaysia (Lee and Khalid 2016), Mexico (Arceo-Gomez and Campos-Vazques 2014; Campos-Vazques and Arceo-Gomez 2015), Norway (Andersson, Jakobsson, and Kotsadam 2012), Peru (Galarza and Yamada 2014, 
2017), and Poland (Wysienska-Di Carlo and Karpinski 2014). HUD has also continued to conduct audit studies with a new iteration of the HDS in 2012 (Turner et al. 2013).

I believe there have been at least four major developments in audit research during the most recent period: (1) continued attempts to adjudicate among types of discrimination, (2) an increased focus on context and the conditions under which discrimination occurs, (3) an increased focus on methodological issues in audit design, and (4) the inclusion of additional data from outside the audit itself. These developments are not mutually exclusive; many studies incorporate two or more of these developments.

Adjudicating among Types of Discrimination

Scholars have long sought to understand the reasons for discrimination and to better adjudicate among types of discrimination (Aigner and Cain 1977; Altonji and Blank 1999; Arrow 1972; Becker 1957; Dymski 2006; Gruyan and Charles 2013). Discrimination research has often focused on whether decision makers discriminate based on a general dislike of a certain group (taste-based discrimination) or based on assumptions about the average characteristics of an individual from that group (statistical discrimination). ${ }^{11}$ Recent audits have attempted to adjudicate between taste-based and statistical discrimination by varying multiple characteristics and examining differences in response rates between types of characteristics (more or less susceptible to taste-based discrimination) and examining interactions with characteristics that might provide information to overcome statistical discrimination (Agerström et al. 2012; Ahmed, Andersson, and Hammarstedt 2010; Auspurg, Hinz, and Schmid 2017; Baldini and Federici 2011; Bosch, Carnero, and Farré 2010; Capéau et al. 2012; Carlsson and Eriksson 2014; Drydakis 2014; Edo, Jacquemet, and Yannelis 2013; Ewens, Tomlin, Wang 2014; Gneezy, List,

\footnotetext{
${ }^{11}$ David Neumark (forthcoming) provides an excellent review of these and other types of discrimination, so I do not go into more detailed explanation here.
} 
and Price 2012; Hanson and Hawley 2014; Hanson and Santas 2014). The results from these studies are somewhat mixed as to whether taste-based or statistical discrimination occurs more often (or some combination of the two). These mixed findings likely stem from the variety of locations and characteristics studied.

Two studies related to taste-based versus statistical discrimination stand out among the rest (Bartoš et al. 2016; Pager 2016). In the first, the authors examined how both an individual characteristic, in this case race, and the type of market can lead to "attention discrimination," or the differential use of available information. The authors set up audits in rental housing and labor markets and found that in the first market, decision makers selected more applicants overall and more often examined additional information from minority applicants. In the later market, decision makers selected fewer applicants overall and more often examined additional information from majority applicants. Thus, discrimination in acquiring information about candidates occurred at the initial stage of selection and varied by the selectivity of the market. We should be cautious to consider how these types of processes - overall response or selection rates in a given market and the differential use of available information - might influence future audits.

In the second, Devah Pager (2016) examined whether firms that discriminated in a previous audit are still in business six years later. Economists suggest that an efficient market should eventually weed out taste-based discrimination since not all employers exhibit that type of discrimination and those who do will pay a penalty for inefficient hiring (Arrow 1973; Becker 1957). Using additional data on firm failure, Pager found that prior discrimination is associated with a firm going out of business. Although other factors may explain this relationship, the findings are at least consistent with taste-based discrimination. 


\section{$\underline{\text { Context and Conditions Under Which Discrimination Occurs }}$}

Another major development during this period has been researchers’ increased focus on context and the conditions under which discrimination occurs. Two aspects of context geographic location and occupation or market characteristics - have played a significant role in recent audits. Those audits that have taken geographic variation into account often examine differences by neighborhood characteristics such as racial, ethnic, immigrant, and SES composition (Acolin, Bostic, Painter 2016; Carlsson and Ericksson 2014, 2015; Carlsson, Reshid, and Rooth 2017; Galster, MacDonald, and Nelson forthcoming; Ghoshal and Gaddis 2015; Hanson and Hawley 2011; MacDonald, Galster, and Dufty-Jones forthcoming). Others have examined geography in more detail by tying discrimination- or prejudice-based theories into the analysis (Besbris et al. 2015, this volume; Gaddis and Ghoshal 2015; Hanson and Hawley 2014; Phillips 2016a). A second strand of research has considered if levels of discrimination are influenced by the types or composition of occupations (Albert, Escot, and Fernandez-Cornejo 2011; Andriessen et al. 2012; Booth and Leigh 2010; Bursell 2014; Carlsson 2011; Derous, Ryan, and Nguyen 2012; Zhou, Zhang, and Song 2013), whether a job is a promotion (Baert, De Pauw, and Deschacht 2016), whether an applicant is overqualified (Baert and Verhaest 2014; Verhaest et al. forthcoming), or market tightness or slackness (Baert et al. 2015; Carlsson, Fumarco, and Rooth 2015; Farber, Silverman, and von Wachter 2017; Vuolo, Uggen, and Lageson 2017a).

Some researchers have varied multiple individual characteristics simultaneously and examined interactions to try to capture a broader spectrum of the decision-making process. In particular, recent audits have focused on interactions between race/ethnicity and educational credentials (Carbonaro and Schwarz this volume; Darolia et al. 2015; Deming et al. 2016; Gaddis 
2015, 2017d; Lee and Khalid 2016; Nunley et al. 2015), race/ethnicity and criminal record (Ahmed and Lang 2017; Decker et al. 2015; Uggen et al. 2014), race/ethnicity and sexual orientation (Mazziotta, Zerr, and Rohmann 2015) and various combinations of personal characteristics and human capital characteristics (Andersson, Jakobsson, and Kotsadam 2012; Baert and Vujic 2016; Baert et al. 2016b, 2017; Johnson and Lahey 2011; Namingit, Blankenau, and Schwab 2017; Neumark, Burn, and Button 2015; Nunley et al. 2016, 2017; Oreopoulos and Dechief 2012; Pedulla 2016; Phillips 2017).

Some of the most interesting research to examine context and conditions has focused on the effects of policies. In one such study, a team of researchers examined whether discrimination against individuals with a disability varied by whether a company was subject to the Americans with Disabilities Act (ADA) (Ameri et al. forthcoming). The authors found that the ADA reduced discrimination against disabled applicants among employers that were covered under the law. A second study used audit and non-audit data to examine differences in age discrimination across states by differences in anti-discrimination policies (Neumark et al. 2017). The authors found no strong relationship between the strength of state laws and discrimination rates. Finally, a third study used a difference-in-differences design with an audit, multiple time points, and a policy change (Agan and Starr 2016). The authors tested the effect of ban-the-box policies, which prevent an employer from collecting information on criminal record, on levels of racial discrimination in hiring. They found that after ban-the-box policies went into effect, levels of racial discrimination increased. The authors suggest that when employers cannot ask about criminal history, they may engage in statistical discrimination and assume that black applicants have a criminal record. Methodological Issues in Audit Design 
In recent years, scholars have considered at least three methodological issues in audit design: (1) paired vs nonpaired audits, (2) indirect signals of race, and (3) the Heckman critique of unobserved differences between groups. First, in my experience, the question of paired versus non-paired audit design is often a concern during IRB submission and subsequent discussions. A paired audit design opens the research up to an increased chance of experiment discovery because decision makers can potentially see two applicants or inquiries that are very similar. However, conventional wisdom suggests that the paired design is more statistically efficient, decreases the amount of time required for data collection, and can lead to a larger sample size (Lahey and Beasley this volume). In at least two cases, fear of experiment discovery led to a preemptive non-paired audit design (Weichselbaumer 2015, 2016). Additionally, researchers have raised concerns that paired designs may influence findings of discrimination because researchers insert fake applicants into the applicant pool without knowing the composition of that applicant pool (Phillips 2016b; Weichselbaumer 2015). Employers compare applicants to each other and by inserting more than one applicant into a particular pool, researchers may influence the process. In fact, Phillips (2016b) developed a method to test these effects and found that "adjusting for applicant pool composition increases measured discrimination by $20 \%$ on average” (2016b: 1). Moreover, proper power analysis suggests that paired audits are not needed as often as researchers think (Vuolo, Uggen, and Lageson 2016, this volume).

I have devoted considerable time and effort to a second methodological concern - the indirect signaling of race through names (Gaddis 2017a, 2017b, 2017c, forthcoming). With correspondence audits, researchers lose the ability to directly convey race through appearance and must rely on an indirect signal, such as a name, to signal race. Although prior research occasionally raised some concerns about the signal of names (e.g. Bertrand and Mullainathan 
2004), only $17.5 \%$ of the studies I reviewed used pretests to examine the perception of names used in an audit (Gaddis forthcoming). My work has shown that racial perceptions of white and black names are often linked with social class (Gaddis forthcoming), Hispanic names are strongly identified (Gaddis 2017a), immigrant generational status can be discerned through names (Gaddis 2017b), and, perhaps most importantly, audit findings are strongly linked to the names researchers use (Gaddis 2017c). Still, more needs to be done to examine the signals we use in audit studies (see next section).

The final area of methodological inquiry concerns the Heckman critique of unobserved differences between groups and has received the most scholarly attention of the three issues discussed here (Heckman 1998; Heckman and Siegelman 1993). James Heckman’s critique is that scholars using the audit design assume that unobservable characteristics have equal means across groups, yet scholars cannot confirm that. Heckman suggests that multiple components could enter into the decision-making process - some controlled for by audit design and others unknown to designers but known to the decision makers. In other words, characteristics that researchers do not include on a resume or in an email. These components combine to place a candidate above or below the threshold to receive a response. If the two groups being studied have different variances on these important unobserved components, audit studies may over or underestimate discrimination or detect an effect when there is not one. David Neumark (forthcoming) provides a more detailed discussion of this critique and has devised a method to produce an unbiased estimate of discrimination and avoid this critique (2012). Neumark (2012) reanalyzed Bertrand and Mullainathan's (2004) original audit data using this method to account for the variance of unobservables and found stronger evidence of racial discrimination. Two individual studies have implemented Neumark's method, with no clear pattern regarding bias 
(Baert 2015; Neumark, Burn, and Button 2016). Two other studies have re-analyzed data from multiple audits and suggest that employment audits appear to be susceptible to the Heckman critique (Carlsson, Fumarco, and Rooth 2014; Neumark and Rich 2016). The authors of these two studies advise that scholars still have a lot of work to do in improving the audit method by more directly addressing this critique.

\section{Including Additional Data from Outside the Audit}

A final major development in recent audit research is the inclusion of additional data from outside the audit itself, something done by many of the studies already mentioned in this section. Several researchers have included geographic data on neighborhood and city characteristics to supplement audits (e.g. Acolin, Bostic, Painter 2016; Carlsson and Ericksson 2014, 2015; Ghoshal and Gaddis 2015; Hanson and Hawley 2011). Others have included other types of available data, such as firm closure (Pager 2016), mortgage lender transactions (Hanson, Hawley, and Martin 2017), and existing survey data on racial/ethnic attitudes and beliefs (Carlsson and Eriksson 2017; Carlsson and Rooth 2012).

One of the most promising avenues of inquiry into discrimination is the combination of audits with other methods of data collection. Following in the footsteps of Pager and Quillian (2005), researchers are increasingly obtaining a second round of information from the same individuals who previously participated in an audit. Some researchers have followed-up with employers to administer implicit association tests (IATs) to examine the connection between implicit bias and discrimination (Agerström and Rooth 2011; Rooth 2010). Other researchers have followed-up with surveys or interviews after an audit to attempt to better understand the reasons behind discriminatory actions (Bonnet et al. 2016; Midtbøen 2014, 2015, 2016; Zussman 2013). Although institutional review boards (IRBs) may be hesitant to allow researchers to 
engage in multiple points of contact with audit participants, some researchers have successfully shown that additional methods of data collection do not necessarily need to follow up with the original audit participants (Gaddis and Ghoshal 2017; Kang et al. 2015).

I believe that researchers should continue in the direction of the trends discussed above adjudicating among types of discrimination, focusing on context and the conditions under which discrimination occurs, focusing on methodological issues in audit design, and including additional data from outside audits. In particular, researchers should try to include geographic data in audits, given the wide availability of geographic data and the relative simplicity and usefulness of including such data in analyzing audit outcomes. Next, in the final section, I outline some limitations of correspondence audits and return to the issues discussed in this section with additional thoughts on continuing to improve correspondence audits.

\section{LIMITATIONS OF AND WAYS TO IMPROVE CORRESPONDENCE AUDITS}

Despite the rapid advancement of correspondence audits over the past two decades, several serious limitations exist that scholars must continue to address. Limitations of in-person audits have been covered by others in detail, particularly James Heckman (1998; Heckman and Siegelman 1993), and I draw upon that work here. However, correspondence audits often have their own unique quirks and limitations. By no means is this section intended to be an exhaustive list of all the limitations of correspondence audits, but instead some areas where I see the biggest problems and/or new potential solutions. I highly recommend the reader turn to David Pedulla's chapter (this volume) for a more extensive and detailed discussion of these and other issues. 
Perhaps most important is the general limitation of audit studies in uncovering mechanisms rather than simply documenting the existence of discrimination. As discussed in the previous section, recent work has started to expand our knowledge in this area in increasingly innovative ways. Not all questions will lend themselves to design tricks built into studies to help discover mechanisms, nor can researchers always implement complex factorial designs to test potential mechanisms. My recommendation is that researchers should be more open to collecting survey experiment data side-by-side with field data from audit studies (e.g. Diehl et al. 2013; Gaddis and Ghoshal 2017). The deception of the audit study may allow us to document discrimination but a similar scenario presented as a survey experiment may allow us to explore potential mechanisms with the right questions. Moreover, the rise of Amazon’s Mechanical Turk (MTurk) makes collecting survey experiment data relatively quick and cheap (Campbell and Gaddis forthcoming; Porter, Verdery, and Gaddis 2017). In ongoing work combing an audit with a survey experiment, I find that roommate discrimination against many different racial and ethnic groups is driven by issues of cultural fit. However, blacks face higher levels of discrimination than others due to negative perceptions about financial stability and courteousness, despite respondents receiving the same information about all racial/ethnic groups (Gaddis and Ghoshal 2017). These findings would not have come to light if we had implemented a correspondence audit or survey experiment alone.

A second major limitation of correspondence audits is indirect signaling of characteristics. Correspondence audits often require signals to be sent through names, statements, lists, or other text embedded in communications. In my own research, I have worked to understand how names can be used to signal race, ethnicity, and immigrant status (Gaddis 2017a, 2017b, forthcoming) and have found that signals of race are conflated with social class and that 
conflation explains differences in response rates across previous correspondence audits (Gaddis 2017c). Still, more work needs to be done to ensure that construct validity is high when we need to indirectly signal characteristics in correspondence audits. At a minimum, researchers should pretest their signals in a scientific manner to help increase construct validity. Additionally, more work is needed to explore the possibility of alternate signals since there is often more than one way to indirectly signal a characteristic.

The signaling of characteristics is also related to the way we can conduct correspondence audits and the level of external validity of those audits. A characteristic such as race or gender may convey different things depending on how it is signaled and the context in which it is signaled. Not only are correspondence audits only as good as the signals they use to convey key characteristics, but audit studies also only tell us about a specific avenue of correspondence with a specific signal. For example, real job seekers may use any combination of online job sites, personal and professional networks, alumni resources, headhunters, and employment events. How race is conveyed and the meaning of race likely vary across these different means of searching for a job. Static, written signals - such as name, professional affiliations, or even checking a box for race - may cue stereotypes about race. Dynamic, interpersonal signals - such as a discussion with a reference or interaction with the individual - may permit more flexibility in thoughts about race. Although others have raised concerns about how audits begin with a narrow sampling frame (e.g., jobs or housing posted in newspapers or on websites) and limit generalizability to the entire job or housing search process (Friedman 2015; Gaddis 2015; Heckman and Siegelman 1993; Pitingolo and Ross 2015), I suggest that the narrow sampling frame also limits our knowledge of discrimination processes only to those that can be conveyed through certain static and often indirect signals. 
Although in-person audits have occasionally examined multiple outcomes at various stages of the processes they study (Bendick, Jackson, and Reinoso 1994; Pager, Western, and Bonikowski 2009; Turner, Fix, and Struyk 1991), correspondence audits have been almost entirely limited to studying outcomes at the initial contact phase. Critics have pointed out that we do not know whether the disparities witnessed at the initial contact phase lead to disparities at later phases (Heckman 1998; Heckman and Siegelman 1993). Others have used nationally representative data to simulate the effect of employer callback disparities on wages (Lanning 2013). Still, as my own research shows, we should use all the information possible to expand the outcomes examined by audit studies. Additional information in both employment (Gaddis 2015) and housing advertisements (Gaddis and Ghoshal 2015, 2017; Ghoshal and Gaddis 2015) should be used to our advantage.

Furthermore, we should consider additional ways that audits might be tweaked to examine other outcomes. In employment audits, do human resources staff visit LinkedIn or Facebook pages, contact references, or attempt multiple contacts with applicants at different rates? Some recent articles provide excellent examples of the directions audits might continue to go in the future (Acquisti and Fong 2015; Baert forthcoming; Bartoš et al. 2016; Blommaert, Coenders, and van Tubergen 2014; Butler and Crabtree forthcoming; and see Crabtree this volume for more discussion). Additionally, is it possible to return to the strategies of earlier audits and use a sub-sample with real humans to proceed deeper into processes, such as sending trained assistants into in-person or Skype interviews? I believe that future waves of audit studies will need to be creative and incorporate more variety in outcomes to push this method forward.

\section{THIS VOLUME AND ONLINE RESOURCES}


This volume is organized into three broad sections: (1) The Theory Behind and History of Audit Studies, (2) The Method of Audit Studies: Design, Implementation, and Analysis, and (3) Nuance in Audit Studies: Context, Mechanisms, and the Future. You are reading the first chapter of the first section and, hopefully, you already have a better understanding of audit studies. In the second chapter, Fran Cherry and Marc Bendick discuss the historical connections between activism and scholarship through audits. Their chapter highlights the potential power of audit studies to not just document discrimination but reduce it as well. The authors advocate for a return to scholar-activism and outline four characteristics that will help facilitate that path. In the third chapter, Stijn Baert provides an excellent overview of labor market correspondence audits conducted since Bertrand and Mullainathan’s groundbreaking study. Baert organizes these studies across two major dimensions: discrimination treatment characteristic, which includes nine federally-banned (U.S.) and five state-banned discrimination grounds, and country of analysis. Overall, the author provides information on 90 labor market correspondence audits across 24 countries.

The chapters in the second section give the reader a "behind-the-scenes" look at the nuts and bolts of audit studies, as well as serve as a guide for designing and implementing your own audit studies. In the fourth chapter, Joanna Lahey and Ryan Beasley outline a number of technical aspects related to designing and conducting a correspondence audit. They cover issues of validity, participant selection, timing, technical design of correspondence, matching, sample size, and analysis, among other issues. Their chapter serves as a terrific starting point for anyone needing more information on creating their own audit. In the fifth chapter, Charles Crabtree extends this discussion by providing a detailed overview of designing and implementing an email correspondence audit. He provides information on sample selection, collecting email 
addresses, sending emails, and collecting outcomes. This chapter is particularly useful in thinking about automating an audit design using programming scripts. A coding appendix for this chapter will be available at auditstudies.com. In the sixth chapter, Mike Vuolo, Christopher Uggen, and Sarah Lageson offer an extensive consideration of matched versus non-matched audit designs. They provide statistical guidelines for when matching is appropriate and show that non-matched audit designs can be more efficient. Additionally, they raise some important substantive points for researchers to think about when deciding to use a matched or non-matched design.

Finally, the chapters in the third section provide even deeper insight into the audit process by discussing more design considerations and nuance. In the seventh chapter, William Carbonaro and Jonathan Schwarz outline their thought process in selecting cities in which to conduct an audit, the difficulties of using a small city, the unknowns of the employer side of an audit, and the choice of jobs for a sample. This chapter shares important "lessons learned" from experienced researchers. Although scholars cannot think through all of the possible variables involved in designing and fielding an audit in advance, I think this chapter serves as a great example of how auditing is an incredibly difficult and nuanced process. In the eighth chapter, Max Besbris, Jacob William Faber, Peter Rich, and Patrick Sharkey show how an audit can be designed to investigate a non-individual-level treatment. They use an audit to examine the mechanism of place-based stigma in the relationship between neighborhoods and outcomes for residents of those neighborhoods. Their audit, the discussion of thinking about signaling characteristics, and the theory-based use of geography provide a strong example of what future audits might looks like. In the ninth and final chapter, David Pedulla explores how audits might change and develop in the coming years. He highlights research that identifies mechanisms, 
examines when and where discrimination happens, and scrutinizes issues of representativeness. David's chapter serves as a terrific bookend to this volume and should be read closely by anyone wishing to implement an audit of their own.

On behalf of the other contributors, we hope you find this volume informative and useful. We have a number of overarching goals for this book: (1) to create a go-to guide for anyone looking to conduct an audit study, (2) to provide resources for using the audit method, both within this book and online, and (3) to record the history of audits. For more information on audits, please consult our website at www.auditstudies.com and take a look at the recommend reading list below. 


\section{RECOMMENDED READING}

\section{Comprehensive Articles and Books on Audits}

"Situation Testing for Employment Discrimination in the United States." 2007. By Marc Bendick Jr. Horizons Stratégiques, 3:17-39.

Clear and Convincing Evidence: Measurement of Discrimination in America. 1993. Edited by Michael Fix and and Raymond J. Struyk. Washington, DC: The Urban Institute.

“Experimental Research on Labor Market Discrimination.” Forthcoming. By David Neumark. Journal of Economic Literature.

"The Use of Field Experiments for Studies of Employment Discrimination: Contributions, Critiques, and Directions for the Future.” 2007. By Devah Pager. The ANNALS of the American Academy of Political and Social Science, 609:104-33.

\section{Reviews of Audits and Discrimination Research}

"What Have We Learned from Paired Testing in Housing Markets?” 2015. By Sun Jung Oh and John Yinger. Cityscape: A Journal of Policy Development and Research, 17(3):15-59.

"The Sociology of Discrimination: Racial Discrimination in Employment, Housing, Credit, and Consumer Markets.” 2008. By Devah Pager and Hana Shepherd. Annual Review of Sociology, 34:181-209.

"Field Experiments of Discrimination in the Market Place.” 2002. By Peter A. Riach and Judith Rich. The Economic Journal, 112:F480-F518.

"What Do Field Experiments of Discrimination in Markets Tells Us? A Meta-Analysis of Studies Conducted Since 2000.” 2014. By Judith Rich. Available at SSRN: https://ssrn.com/abstract=2517887

“A Multidisciplinary Survey on Discrimination Analysis.” 2013. By Andrea Romei and Salvatore Ruggieri. The Knowledge Engineering Review, 29(5):582-638.

\section{Meta-Analyses of Audits}

"The Persistence of Racial Discrimination: A Meta-Analysis of Field Experiments in Hiring over Time.” Forthcoming. By Lincoln Quillian, Devah Pager, Ole Hexel, and Arnfinn Midtbøen. Proceedings of the National Academy of Sciences. 
"Ethnic Discrimination in Hiring Decisions: A Meta-Analysis of Correspondence Tests 1990-2015.” 2016. By Eva Zschirnt and Didier Ruedin. Journal of Ethnic and Migration Studies, 42(7):1115-34.

\section{Articles and Books on the Methodology of Audits, Discrimination, and Field Experiments}

\section{Field Experiments (General)}

"Field Experiments Across the Social Sciences.” 2017. By Delia Baldassarri and Maria Abascal. Annual Review of Sociology, 43:41-73.

Field Experiments: Design, Analysis ,and Interpretation. 2012. By Alan S. Gerber and Donald P. Green. New York, NY: W.W. Norton.

"The Principles of Experimental Design and Their Application in Sociology.” 2013. By Michelle Jackson and D. R. Cox. Annual Review of Sociology, 39:27-49.

Audits (General)

Audit Studies: Behind the Scenes with Theory, Method, and Nuance. 2017. Edited by S. Michael Gaddis. Springer.

Discrimination (General)

Measuring Racial Discrimination. 2004. By Rebecca N. Blank, Marilyn Dabady, and Constance F. Citro. Washington, DC: The National Academies Press.

Automating Resume Creation for Audits

“Computerizing Audit Studies.” 2009. By Joanna N. Lahey and Ryan A. Beasley. Journal of Economic Behavior \& Organization, 70(3):508-14.

Critiques of Audits and Solutions

"Detecting Discrimination.” 1998. By James J. Heckman. Journal of Economic Perspectives, 12(2):101-16.

“The Urban Institute Audit Studies: Their Methods and Findings.” 1993. By James J. Heckman and Peter Siegelman. In Clear and Convincing Evidence: Measurement of Discrimination in America, edited by M. Fix and R. J. Struyk, 187-258. Washington, DC: The Urban Institute Press.

"Detecting Discrimination in Audit and Correspondence Studies.” 2012. By David Neumark. The Journal of Human Resources, 47(4):1128-57. 
"Do Field Experiments on Labor and Housing Markets Overstate Discrimination? A Re-Examination of the Evidence.”2016. By David Neumark and Judith Rich. Available at NBER: http://www.nber.org/papers/w22278

\section{$\underline{\text { Signaling Characteristics in Audits }}$}

"How Black are Lakisha and Jamal? Racial Perceptions from Names Used in Correspondence Audit Studies.” Forthcoming. By S. Michael Gaddis. Sociological Science.

"Racial/Ethnic Perceptions from Hispanic Names: Selecting Names to Test for Discrimination.” 2017. By S. Michael Gaddis. Available at SSRN: https://ssrn.com/abstract=2975829

"Assessing Immigrant Generational Status from Names: Scientific Evidence for Experiments.” 2017. By S. Michael Gaddis. Available at SSRN: https://ssrn.com/abstract=3022217

“Auditing Audit Studies: The Effects of Name Perception and Selection on Social Science Measurement of Racial Discrimination.” 2017. By S. Michael Gaddis. Available at SSRN: https://ssrn.com/abstract=3022207

$\underline{\text { Statistical Analysis of Audits }}$

"Statistical Power in Experimental Audit Studies: Cautions and Calculations for Matched Tests with Nominal Outcomes.” 2016. By Mike Vuolo, Christopher Uggen, and Sarah Lageson. Sociological Methods \& Research, 45(2):260-303.

\section{Theoretical Articles and Books on Discrimination}

“Taste-Based or Statistical Discrimination: The Economics of Discrimination Returns to its Roots.” 2013. By Jonathan Guryan and Kerwin Kofi Charles. The Economic Journal, 123:F417-32.

Theorizing Discrimination in an Era of Contested Prejudice: Discrimination in the United States, Volume 1. 2008. By Samuel Roundfield Lucas. Philadelphia, PA: Temple University Press. 


\section{REFERENCES}

Acolin, Arthur, Raphael Bostic, and Gary Painter. 2016. "A Field Study of Rental Market Discrimination across Origins in France.” Journal of Urban Economics, 95:49-63.

Acquisti, Alessandro, and Christina M. Fong. 2015. "An Experiment in Hiring Discrimination via Online Social Networks.” Available at SSRN: https://ssrn.com/abstract=2031979

Adam, Barry D. 1981. "Stigma and Employability: Discrimination by Sex and Sexual Orientation in the Ontario Legal Profession." Canadian Review of Sociology, 18(2):216-21.

Adida, Claire L., David D. Laitin, and Marie-Anne Valfort. 2010. "Identifying Barriers to Muslim Integration in France.” Proceedings of the National Academy of Sciences, 107(52):22384-90.

Agan, Amanda Y., and Sonja B. Starr. 2016. "Ban the Box, Criminal Records, and Statistical Discrimination: A Field Experiment.” Available at SSRN: https://ssrn.com/abstract=2795795

Agerström, Jens, Fredrik Björklund, Rickard Carlsson, and Dan-Olof Rooth. 2012. "Warm and Competent Hassan = Cold and Incompetent Eric: A Harsh Equation of Real-Life Hiring Discrimination.” Basic and Applied Social Psychology, 34(4):359-66.

Agerström, Jens, and Dan-Olof Rooth. 2011. "The Role of Automatic Obesity Stereotypes in Real Hiring Discrimination.” Journal of Applied Psychology, 96(4):790-805.

Ahmed, Ali M., Lina Andersson, and Mats Hammarstedt. 2008. “Are Lesbians Discriminated against in the Rental Housing Market? Evidence from a Correspondence Testing Experiment.” Journal of Housing Economics, 17(3):234-8.

Ahmed, Ali M., Lina Andersson, and Mats Hammarstedt. 2010. "Can Discrimination in the Housing Market be Reduced by Increasing the Information about the Applicants?” Land Economics, 86(1):79-90.

Ahmed, Ali M., Lina Andersson, and Mats Hammarstedt. 2012. "Does Age Matter for Employability? A Field Experiment on Ageism in the Swedish Labour Market." Applied Economics Letters, 19(4):403-406.

Ahmed, Ali M., Lina Andersson, and Mats Hammarstedt. 2013. “Are Gay Men and Lesbians Discriminated Against in the Hiring Process?” Southern Economic Journal, 79(3):565-85.

Ahmed, Ali M., and Mats Hammarstedt. 2008. "Discrimination in the Rental Housing Market: A Field Experiment on the Internet." Journal of Urban Economics, 64(2):362-372. 
Ahmed, Ali M., and Mats Hammarstedt. 2009. "Detecting Discrimination against Homosexuals: Evidence from a Field Experiment on the Internet." Economica, 76(303):588-597.

Ahmed, Ali M., and Elisabeth Lang. 2017. “The Employability of Ex-Offenders: A Field Experiment in the Swedish Labor Market.” IZA Journal of Labor Policy, 6(6):1-23.

Aigner, Dennis J., and Glen G. Cain. 1977. "Statistical Theories of Discrimination in Labor Markets.” Industrial and Labor Relations Review, 30(2):175-87.

Albert, Rocío, Lorenzo Escot, and José Andrés Fernández-Cornejo. 2011. “A Field Experiment to Study Sex and Age Discrimination in the Madrid Labour Market.” The International Journal of Human Resource Management, 22(2):351-75.

Allasino, E., E. Reyneri, A. Venturini, and G. Zincone. 2004. Labour Market Discrimination against Migrant Workers in Italy. Geneva: International Labour Office.

Allred, Brent B., Michael G. Findley, Daniel Nielson, and J.C. Sharman. 2017. “Anonymous Shell Companies: A Global Audit Study and Field Experiment in 176 Countries.” Journal of International Business Studies, 48(5):596-619.

Altonji, Joseph G., and Rebecca M. Blank. “Race and Gender in the Labor Market.” In Handbook of Labor Economics, edited by O. Ashenfelter and D. Card, Volume 3C:3143-259. New York, NY: Elsevier.

Ameri, Mason, Lisa Schur, Meera Adya, F. Scott Bentley, Patrick McKay, and Douglas Kruse. Forthcoming. "The Disability Employment Puzzle: A Field Experiment on Employer Hiring Behavior.” ILR Review. DOI: 10.1177/0019793917717474

Anagol, Santosh, Shawn Cole, and Shayak Sarkar. 2017. "Understanding the Advice of Commissions-Motivated Agents: Evidence from the Indian Life Insurance Market.” The Review of Economics and Statistics, 99(1):1-15.

Andersson, Lisa, Niklas Jakobsson, and Andreas Kotsadam. 2012. “A Field Experiment of Discrimination in the Norwegian Housing Market: Gender, Class, and Ethnicity.” Land Economics, 88(2):233-240.

Andriessen, Iris, Eline Nievers, Jaco Dagevos, and Laila Faulk. 2012. "Ethnic Discrimination in the Dutch Labor Markets: Its Relationship with Job Characteristics and Multiple Group Membership.” Work and Occupations, 39(3):237-69.

Arai, Mahmood, Moa Bursell, and Lena Nekby. 2016. “The Reverse Gender Gap in Ethnic Discrimination: Employer Stereotypes of Men and Women with Arabic Names.” International Migration Review, 50(2):385-412. 
Arceo-Gomez, Eva O., and Raymundo M. Campos-Vazquez. 2014. "Race and Marriage in the Labor Market: A Discrimination Correspondence Study in a Developing Country.” The American Economic Review, 104(5):376-380.

Ariel, Barak, Ilanit Tobby-Alimi, Irit Cohen, Mazal Ben Ezra, Yafa Cohen, and Gabriela Sosinski. 2015. "Ethnic and Racial Employment Discrimination in Low-Wage and High-Wage Markets: Randomized Controlled Trials Using Correspondence Tests in Israel.” The Law \& Ethics of Human Rights, 9(1):113-39.

Arrijn, Peter, Serge Feld, and André Nayer. 1998. Discrimination in Access to Employment on Grounds of Foreign Origin: The Case of Belgium. Geneva: International Labour Office, Conditions of Work Branch.

Arrow, Kenneth. 1972. "Some Mathematical Models of Race Discrimination in the Labor Market.” In Racial Discrimination in Economic Life, edited by A.H. Pascal, 187-204. Lexington, MA: D.C. Heath.

Arrow, Kenneth. 1973. “The Theory of Discrimination.” In Discrimination in Labor Market, edited by O. Ashenfelter and A. Rees, 3-33. Princeton, NJ: Princeton University Press.

Attström, K. 2007. Discrimination against Native Swedes of Immigrant Origin in Access to Employment. Geneva: International Labour Office.

Auspurg, Katrin, Thomas Hinz, and Laura Schmid. 2017. "Contexts and Conditions of Ethnic Discrimination: Evidence from a Field Experiment in a German Housing Market.” Journal of Housing Economics, 35:26-36.

Ayers, Ian. 1991. "Fair Driving: Gender and Race Discrimination in Retail Car Negotiations.” Harvard Law Review, 104(4):817-72.

Ayers, Ian, and Peter Siegelman. 1995. "Race and Gender Discrimination in Bargaining for a New Car.” The American Economic Review, 85(3):304-21.

Baert, Stijn. 2014a. "Wage Subsidies and Hiring Chances for the Disabled: Some Causal Evidence.” The European Journal of Health Economics, 17(1):71-86.

Baert, Stijn. 2014b. “Career Lesbians. Getting Hired for not Having Kids?” Industrial Relations Journal, 45(6):543-561.

Baert, Stijn. 2015. "Field Experimental Evidence on Gender Discrimination in Hiring: Biased as Heckman and Siegelman Predicted?” Economics: The Open-Access, Open-Assessment E-Journal, 9(25):1-11.

Baert, Stijn. 2016. "Wage Subsidies and Hiring Chances for the Disabled: Some Causal Evidence.” The European Journal of Health Economics, 17(1):71-86. 
Baert, Stijn. 2017. "Hiring Discrimination: An Overview of (Almost) All Correspondence Experiments Since 2005.” In Audit Studies: Behind the Scenes with Theory, Method, and Nuance, edited by S. M. Gaddis, pXX-pXX. Springer.

Baert, Stijn. Forthcoming. "Facebook Profile Picture Appearance Affects Recruiters' First Hiring Decisions.” New Media \& Society. DOI: 10.1177/1461444816687294

Baert, Stijn, Andrea Albanese, Sofie du Gardein, Jolien Ovaere, and Jarno Stappers. 2017. "Does Work Experience Mitigate Discrimination?” Economics Letters, 155:35-8.

Baert, Stijn, and Pieter Balcaen. 2013. "The Impact of Military Work Experience on Later Hiring Chances in the Civilian Labour Market. Evidence from a Field Experiment.” Economics: The Open-Access, Open-Assessment E-Journal, 7(37):1-17.

Baert, Stijn, Bart Cockx, Niels Gheyle, and Cora Vandamme. 2015. “Is There Less Discrimination in Occupations Where Recruitment is Difficult?” ILR Review, 68(3):467-500.

Baert, Stijn, Ann-Sophie de Pauw, and Nick Deschacht. 2016. "Do Employer Preferences Contribute to Sticky Floors?” ILR Review, 69(3):714-36.

Baert, Stijn, Sarah de Visschere, Koen Schoors, Désirée Vandenberge, and Eddy Omey. 2016. "First Depressed, then Discriminated Against?" Social Science \& Medicine, 170:247-54.

Baert, Stijn, Jennifer Norga, Yannick Thuy, and Marieke van Hecke. 2016. "Getting Grey Hairs in the Labour Market. An Alternative Experiment on Age Discrimination." Journal of Economic Psychology, 57:86-101.

Baert, Stijn, and Eddy Omey. 2015. "Hiring Discrimination Against Pro-Union Applicants: The Role of Union Density and Firm Size.” De Economist, 163(3):263-80.

Baert, Stijn, and Dieter Verhaest. 2014. "Unemployment or Overeducation: Which is a Worse Signal to Employers?” Available at SSRN: https://ssrn.com/abstract=2468488

Baert, Stijn, and Elsy Verhofstadt. 2015. "Labour Market Discrimination against Former Juvenile Delinquents: Evidence from a Field Experiment.” Applied Economics, 47(11):1061-1072.

Baert, Stijn, and Suncica Vujic. 2016. "Immigrant Volunteering: A Way out of Labour Market Discrimination?” Economics Letters, 146:95-8.

Bailey, John, Michael Wallace, and Bradley Wright. 2013. “Are Gay Men and Lesbians Discriminated against when Applying for Jobs? A Four-City, Internet-Based Field Experiment.” Journal of Homosexuality, 60(6):873-894. 
Baldassarri, Delia, and Maria Abascal. 2017. "Field Experiments Across the Social Sciences." Annual Review of Sociology, 43:41-73.

Baldini, Massimo, and Marta Federici. 2011. "Ethnic Discrimination in the Italian Rental Housing Market." Journal of Housing Economics, 20(1):1-14.

Banerjee, Abhijit, Marianne Bertrand, Saugato Datta, and Sendhil Mullainathan. 2009. "Labor Market Discrimination in Delhi: Evidence from a Field Experiment.” Journal of Comparative Economics, 37(1):14-27.

Bartoš, Vojtěch, Michal Bauer, Julie Chytilová, and Filip Matějka. 2016. “Attention Discrimination: Theory and Field Experiments with Monitoring Information Acquisition.” The American Economic Review, 106(6):1437-1475.

Bavan, Meena. 2007. “Does Housing Discrimination Exist Based on the 'Color' of an Individual's Voice?” Cityscape, 9(1):93-107.

Becker, Gary S. 1957. The Economics of Discrimination. Chicago, IL: The University of Chicago Press.

Bendick, Jr., Marc. 1989. Auditing Race Discrimination in Employment: A Research Design. Washington, D.C.: The Urban Institute.

Bendick, Jr., Marc. 2007. "Situation Testing for Employment Discrimination in the United States.” Horizons Stratégiques, 3:17-39.

Bendick, Jr., Marc, Lauren E. Brown, and Kennington Wall. 1999. "No Foot in the Door: An Experimental Study of Employment Discrimination against Older Workers." Journal of Aging \& Social Policy, 10(4):5-23.

Bendick, Jr., Marc, Charles W. Jackson, and Victor A. Reinoso. 1994. "Measuring Employment Discrimination through Controlled Experiments.” The Review of Black Political Economy, 23(1):25-48.

Bendick, Jr., Marc, Charles W. Jackson, Victor A. Reinoso, and Laura E. Hodges. 1991. "Discrimination against Latino Job Applicants: A Controlled Experiment." Human Resource Management, 30(4):469-84.

Bendick, Jr., Marc, Charles W. Jackson, and J. Horacio Romero. 1997. "Employment Discrimination Against Older Workers: An Experimental Study of Hiring Practices." Journal of Aging \& Social Policy, 8(4):25-46.

Bendick, Jr., Marc, Rekha Eanni Rodriguez, and Sarumathi Jayaraman. 2010. "Employment Discrimination in Upscale Restaurants: Evidence from Matched Pair Testing.” The Social Science Journal, 47(4):802-18. 
Bengtsson, Ragnar, Ellis Iverman, and Björn Tyrefors Hinnerich. 2012. "Gender and Ethnic Discrimination in the Rental Housing Market.” Applied Economics Letters, 19(1):1-5.

Bertrand, Marianne, and Sendhil Mullainathan. 2004. “Are Emily and Greg More Employable than Lakisha and Jamal? A Field Experiment on Labor Market Discrimination.” The American Economic Review, 94(4):991-1013.

Besbris, Max, Jacob William Faber, Peter Rich, and Patrick Sharkey. 2015. "Effect of Neighborhood Stigma on Economic Transactions.” Proceedings of the National Academy of Sciences, 112(16):4994-8.

Besbris, Max, Jacob William Faber, Peter Rich, and Patrick Sharkey. 2017. “The Geography of Stigma: Experimental Methods to Identify the Penalty of Place.” In Audit Studies: Behind the Scenes with Theory, Method, and Nuance, edited by S. M. Gaddis, pXX-pXX. Springer.

Birkelund, Gunn Elisabeth, Kristian Heggebø, and Jon Rogstad. 2017. “Additive or Multiplicative Disadvantage? The Scarring Effects of Unemployment for Ethnic Minorities.” European Sociological Review, 33(1):17-29.

Blank, Rebecca M., Marilyn Dabady, and Constance F. Citro. 2004. Measuring Racial Discrimination. Washington, DC: The National Academies Press.

Blommaert, Lieselotte, Marcel Coenders, and Frank van Tubergen. 2014. "Discrimination of Arabic-Named Applicants in the Netherlands: An Internet-Based Field Experiment Examining Different Phases in Online Recruitment Procedures." Social Forces, 92(3):957-82.

Boggs, Roderic V. O., Joseph M. Sellers, and Marc Bendick, Jr. 1993. "Use of Testing in Civil Rights Enforcement.” In Clear and Convincing Evidence: Measurement of Discrimination in America, edited by M. Fix and R. J. Struyk, 345-75. Washington, DC: The Urban Institute Press.

Bonnet, Francois, Etienee Lalé, Mirna Safi, and Etienne Wasmer. 2016. “Better Residential than Ethnic Discrimination! Reconciling Audit and Interview Findings in the Parisian Housing Market.” Urban Studies, 53(13):2815-33.

Bóo, Florencia López, Martín Rossi, and Sergio S. Urzúa. 2013. “The Labor Market Return to an Attractive Face: Evidence from a Field Experiment.” Economics Letters, 118(1):170-2.

Booth, Alison L., Andrew Leigh. 2010. "Do Employers Discriminate by Gender? A Field Experiment in Female-Dominated Occupations.” Economics Letters, 107(2):236-8.

Booth, Alison L., Andrew Leigh, and Elena Varganova. 2012. "Does Ethnic Discrimination Vary across Minority Groups? Evidence from a Field Experiment." Oxford Bulletin of Economics and Statistics, 74(4):547-573. 
Bosch, Mariano, M. Angeles Carnero, and Lidia Farré. 2010. "Information and Discrimination in the Rental Housing Market: Evidence from a Field Experiment.” Regional Science and Urban Economics, 40(1):11-19.

Bovenkerk, Frank. 1992. Testing Discrimination in Natural Experiments: A Manual for International Comparative Research on Discrimination on the Grounds of 'Race' and Ethnic Origin. Geneva: International Labour Office.

Bovenkerk, Frank, Mitzi J. I. Gras, Dhurender Ramsoedh, M. Dankoor, and A. Havelaar. 1995. Discrimination against Migrant Workers and Ethnic Minorities in Access to Employment in the Netherlands. Geneva: International Labour Office, Employment Department.

Bovenkerk, Frank, Benjamin Kilborne, Francois Raveau, and David Smith. 1979. “Comparative Aspects of Research on Discrimination against Non-White Citizens in Great Britain, France, and the Netherlands.” In Problems in International Comparative Research in the Social Science, edited by J. Berting, F. Geyer, and R. Jurkovich, 105-22. Oxford: Pergamon Press.

Broockman, David E. 2013. "Black Politicians are More Intrinsically Motivated to Advance Blacks’ Interests: A Field Experiment Manipulating Political Incentives.” American Journal of Political Science, 57(3):521-536.

Brown, Colin, and Pat Gay. 1985. Racial Discrimination: 17 Years after the Act. London: Policy Studies Institute.

Bursell, Moa. 2007. What's in a Name? A Field Experiment Test for the Existence of Ethnic Discrimination in the Hiring Process. Stockholm: The Stockholm University Linnaeus Center for Integration Studies, University of Stockholm.

Bursell, Moa. 2014. “The Multiple Burdens of Foreign-Named Men - Evidence from a Field Experiment on Gendered Ethnic Hiring Discrimination in Sweden.” European Sociological Review, 30(3):399-409.

Butler, Daniel M., and David E. Broockman. 2011. "Do Politicians Racially Discriminate against Constituents? A Field Experiment on State Legislators.” American Journal of Political Science, 55(3):463-77.

Butler, Daniel M., and Charles Crabtree. Forthcoming. "Moving Beyond Measurement: Adapting Audit Studies to Test Bias-Reducing Interventions.” Journal of Experimental Political Science.

Butler, Daniel M., and Jonathan Homola. 2017. “An Empirical Justification for the Use of Racially Distinctive Names to Signal Race in Experiments.” Political Analysis, 25(1):122-130. 
Bygren, Magnus, Anni Erlandsson, and Michael Gähler. 2017. "Do Employers Prefer Fathers? Evidence from a Field Experiment Testing the Gender by Parenthood Interaction Effect on Callbacks to Job Applications.” European Sociological Review, 33(3):337-48.

Campbell, Colin, and S. Michael Gaddis. Forthcoming. “'I Don’t Agree with Giving Cash’: A Survey Experiment Examining Support for Public Assistance.” Social Science Quarterly. DOI: $10.1111 /$ ssqu.12338

Campos-Vazquez, Ramundo M., and Eva O. Arceo-Gomez Eva O. 2015. "How Does Explicit Discrimination in Job Ads Interact with Discrimination in Callbacks? Evidence from a Correspondence Study in Mexico City.” Working paper available at: http://repositorio-digital.cide.edu/handle/11651/845

Capéau, Bart, Lieve Eeman, Steven Groenez, and Miet Lamberts. 2012. "Two Concepts of Discrimination: Inequality of Opportunity versus Unequal Treatment of Equals.” Working Paper. Available at: https://www.researchgate.net/profile/Steven_Groenez/ publication/254407466_Two_concepts_of_discrimination_inequality_of_opportunity_ versus_unequal_treatment_of_equals/links/5492c1340cf209fc7e9f7e49.pdf

Carbonaro, William, and Jonathan Schwarz. 2017. "Opportunities and Challenges in Designing and Conducting a Labor Market Resume Study.” In Audit Studies: Behind the Scenes with Theory, Method, and Nuance, edited by S. M. Gaddis, pXX-pXX. Springer.

Carlsson, Magnus. 2010. "Experimental Evidence of Discrimination in the Hiring of First-and Second-Generation Immigrants.” Labour, 24(3):263-78.

Carlsson, Magnus. 2011. "Does Hiring Discrimination Cause Gender Segregation in the Swedish Labor Market?” Feminist Economics, 17(3):71-102.

Carlsson, Magnus, and Stefan Ericksson. 2014. "Discrimination in the Rental Market for Apartments.” Journal of Housing Economics, 23:41-54.

Carlsson, Magnus, and Stefan Ericksson. 2015. "Ethnic Discrimination in the London Market for Shared Housing.” Journal of Ethnic and Migration Studies, 41(8):1276-1301.

Carlsson, Magnus, and Stefan Ericksson. 2017. "Do Attitudes Expressed in Surveys Predict Ethnic Discrimination?” Ethnic and Racial Studies, 40(10):1739-57.

Carlsson, Magnus, Luca Fumarco, and Dan-Olof Rooth. 2014. "Does the Design of Correspondence Studies Influence the Measurement of Discrimination?” IZA Journal of Migration, 3:11

Carlsson, Magnus, Luca Fumarco, and Dan-Olof Rooth. 2015. "Does Labor Market Tightness Affect Ethnic Discrimination in Hiring?” Working paper available at: https://nu.se/globalassets/lmdswp20151.pdf 
Carlsson, Magnus, Abdulaziz Abrar Reshid, and Dan-Olof Rooth. 2017. "Neighborhood Signaling Effects, Commuting Time, and Employment.” Working paper available at: https://nu.se/globalassets/feh/lmdswp201703.pdf

Carlsson, Magnus, and Dan-Olof Rooth. 2007. "Evidence of Ethnic Discrimination in the Swedish Labor Market using Experimental Data.” Labour Economics, 14(4):716-729.

Carlsson, Magnus, and Dan-Olof Rooth. 2012. "Revealing Taste-Based Discrimination in Hiring: A Correspondence Testing Experiment with Geographic Variation.” Applied Economics Letters, 19(18):1861-4.

Carpusor, Adrian G., and William E. Loges. 2006. "Rental Discrimination and Ethnicity in Names.” Journal of Applied Social Psychology, 36(4):934-952.

Cediey, E., and F. Foroni. 2008. Discrimination in Access to Employment on Grounds of Foreign Origin in France. Geneva: International Labour Office.

Chen, Jidong, Jennifer Pan, and Yiqing Xu. 2016. "Sources of Authoritarian Responsiveness: A Field Experiment in China.” American Journal of Political Science, 60(2):383-400.

Cherry, Frances, and Marc Bendick, Jr. 2017. "Making it Count Discrimination Auditing and the Activist Scholar Tradition.” In Audit Studies: Behind the Scenes with Theory, Method, and Nuance, edited by S. M. Gaddis, pXX-pXX. Springer.

Cohen, Adam, and Elizabeth Taylor. 2000. American Pharaoh: Mayor Richard J. Daley - His Battle for Chicago and the Nation. Boston, MA: Back Bay Books.

Correll, Shelley J., Stephen Benard, and In Paik. 2007. "Getting a Job: Is there a Motherhood Penalty?” American Journal of Sociology, 112(5):1297-1338.

Crabtree, Charles. 2017. “An Introduction to Conducting Email Audit Studies.” In Audit Studies: Behind the Scenes with Theory, Method, and Nuance, edited by S. M. Gaddis, pXX-pXX. Springer.

Cross, Harry, Genevieve M. Kenney, Jane Mell, and Wendy Zimmermann. 1990. Employer Hiring Practices: Differential Treatment of Hispanic and Anglo Job Seekers. Washington, D.C.: The Urban Institute Press.

Cui, Ruomeng, Jun Li, and Dennis J. Zhang. 2017. "Discrimination with Incomplete Information in the Sharing Economy: Field Evidence from Airbnb.” Available at SSRN: https://ssrn.com/abstract=2882982

Daniel, W. W. 1968. Racial Discrimination in England. Baltimore, MD: Penguin Books. 
Darolia, Rajeev, Cory Koedel, Paco Martorell, Katie Wilson, and Francisco Perez-Arce. 2015. "Do Employers Prefer Workers who Attend For-Profit Colleges? Evidence from a Field Experiment.” Journal of Policy Analysis and Management, 34(4):881-903.

de Leon, Fernanda L. L., and Sang-Hyun Kim. 2016. "In-Group and Out-Group Biases in the Marketplace: A Field Experiment during the World Cup.” Available at SSRN: https://ssrn.com/abstract=2584414

de Prada, Miguel A., W. Actis, C. Pereda, and R. Perez Molina. 1996. Labour Market Discrimination against Migrant Workers in Spain. Geneva: International Labour Office, Employment Department.

Decker, Scott H., Natalie Ortiz, Cassia Spohn, and Eric Hedberg. 2015. "Criminal Stigma, Race, and Ethnicity: The Consequences of Imprisonment for Employment.” Journal of Criminal Justice, 43(2):108-121.

Deming, David J., Noam Yuchtman, Amira Abulafi, Claudia Goldin, and Lawrence F. Katz. 2016. "The Value of Postsecondary Credentials in the Labor Market: An Experimental Study.” The American Economic Review, 106(3):778-806.

Derous, Eva, Ann Marie Ryan, and Hannah-Hanh D. Nguyen. 2012. "Multiple Categorization in Resume Screening: Examining Effects on Hiring Discrimination Against Arab Applicants in Field and Lab Settings.” Journal of Organizational Behavior, 33(4):544-70.

Deterding, Nicole M., and David S. Pedulla. 2016. "Educational Authority in the 'Open Door' Marketplace: Labor Market Consequences of For-Profit, Nonprofit, and Fictional Educational Credentials.” Sociology of Education, 89(3):155-70.

Diehl, Claudia, Veronika A. Andorfer, Yassine Khoudja, and Karolin Krause. 2013. “Not in My Kitchen? Ethnic Discrimination and Discrimination Intentions in Shared Housing among University Students in Germany.” Journal of Ethnic and Migration Studies, 39(10):1679-97.

Distelhorst, Greg, and Yue Hou. 2014. "Ingroup Bias in Official Behavior: A National Field Experiment in China.” Quarterly Journal of Political Science, 9(2):203-30.

Doleac, Jennifer L., and Luke C. D. Stein. 2013. "The Visible Hand: Race and Online Market Outcomes.” The Economic Journal, 123:F469-92.

Drydakis, Nick. 2009. “Sexual Orientation Discrimination in the Labour Market.” Labour Economics, 16(4):364-72.

Drydakis, Nick. 2010. "Labour Discrimination as a Symptom of HIV: Experimental Evaluation The Greek Case.” Journal of Industrial Relations, 52(2):201-17. 
Drydakis, Nick. 2011a. "Women’s Sexual Orientation and Labor Market Outcomes in Greece.” Feminist Economics, 17(1):89-117.

Drydakis, Nick. 2011b. “Ethnic discrimination in the Greek housing market.” Journal of Population Economics, 24(4):1235-1255.

Drydakis, Nick. 2014. "Sexual Orientation Discrimination in the Cypriot Labour Market. Distastes or Uncertainty?” International Journal of Manpower, 35(5):720-44.

Drydakis, Nick, and Minas Vlassis. 2010. "Ethnic Discrimination in the Greek Labour Market: Occupational Access, Insurance Coverage and Wage Offers.” The Manchester School, 78(3):201-218.

Duguet, Emmanuel, Loic Du Parquet, Yannick L’horty, and Pascale Petit. 2015. “New Evidence of Ethnic and Gender Discriminations in the French Labor Market Using Experimental Data: A Ranking Extension of Responses from Correspondence Tests.” Annals of Economics and Statistics/Annales d'Économie et de Statistique, 117/118:21-39.

Duguet, Emmanuel, Noam Leandri, Yannick L’horty, and Pascale Petit. 2010. “Are Young French Jobseekers of Ethnic Immigrant Origin Discriminated Against? A Controlled Experiment in the Paris Area." Annals of Economics and Statistics/Annales d'Économie et de Statistique, 187-215.

Dymski, Gary A. 2006. “A Discrimination in the Credit and Housing Markets: Findings and Challenges.” Handbook on the Economics of Discrimination, edited by William N. Rodgers III, 215-59. Northampton, MA: Edward Elgar.

Edelman, Benjamin, Michael Luca, and Dan Svirsky. 2017. "Racial Discrimination in the Sharing Economy: Evidence from a Field Experiment.” American Economic Journal: Applied Economics, 9(2):1-22.

Edo, Anthony, Nicolas Jacquemet, and Constantine Yannelis. 2013. “Language Skills and Homophilous Hiring Discrimination: Evidence from Gender- and Racially-Differentiated Applications.” Documents de travail du Centre d'Economie de la Sorbonne. Available at: https://hal.archives-ouvertes.fr/halshs-00877458/

Einstein, Katherine Levine, and David M. Glick. 2017. “Does Race Affect Access to Government Services? An Experiment Exploring Street-Level Bureaucrats and Access to Public Housing.” American Journal of Political Science, 61(1):100-16.

Elmi, Amina, and Maris Mickelsons. 1991. Housing Discrimination Study: Replication of 1977 Study Measures Using Current Data. Washington, D.C.: U.S Department of Housing and Urban Development. 
Eriksson, Stefan, and Dan-Olof Rooth. 2014. "Do Employers Use Unemployment as a Sorting Criterion When Hiring? Evidence from a Field Experiment.” The American Economic Review, 104(3):1014-39.

Esmail, Aneez, and Sam Everington. 1993. "Racial Discrimination against Doctors from Ethnic Minorities.” BMJ: British Medical Journal, 306(6879):691-2.

Esmail, Aneez, and Sam Everington. 1997. “Asian Doctors are Still Being Discriminated Against.” BMJ: British Medical Journal, 314(7094):1619.

Evans, Douglas N. 2016. "The Effect of Criminal Convictions on Real Estate Agent Decisions in New York City.” Journal of Crime and Justice, 39(3):363-379.

Evans, Douglas N., and Jeremy R. Porter. 2015. “Criminal History and Landlord Rental Decisions A New York Quasi-Experimental Study.” Journal of Experimental Criminology, 11(1):21-42.

Ewens, Michael, Bryan Tomlin, and Liang Choon Wang. 2014. "Statistical Discrimination or Prejudice? A Large Sample Field Experiment.” The Review of Economics and Statistics, 96(1):119-34.

Farber, Henry S., Dan Silverman, and Till von Wachter. 2017. "Factors Determining Callbacks to Job Applications by the Unemployed: An Audit Study.” RSF: The Russell Sage Foundation Journal of the Social Science, 3(3):168-201.

Farkas, George, and Keven Vicknair. 1996. “Appropriate Tests of Racial Wage Discrimination Require Controls for Cognitive Skill: Comment on Cancio, Evans, and Maume.” American Sociological Review, 61(4):557-60.

Feins, Judith D., and Rachel G. Bratt. 1983. "Barred in Boston: Racial Discrimination in Housing.” Journal of the American Planning Association, 49(3):344-55.

Feldman, Michelle E., and Allyson J. Weseley. 2013. "Which Name Unlocks the Door? The Effect of Tenant Race/Ethnicity on Landlord Response.” Journal of Applied Social Psychology, 43(S2):E416-25.

Figinski, Theodore F. 2017. “The Effect of Potential Activations on the Employment of Military Reservists: Evidence from a Field Experiment.” ILR Review, 70(4):1037-56.

Firth, Michael. 1981. "Racial Discrimination in the British Labor Market.” Industrial and Labor Relations Review, 34(2):265-72.

Fix, Michael, and Raymond J. Struyk. 1993. Clear and Convincing Evidence: Measurement of Discrimination in America. Washington, DC: The Urban Institute Press. 
Fix, Michael, George C. Galster, and Raymond J. Struyk. 1993. “An Overview of Auditing for Discrimination.” In Clear and Convincing Evidence: Measurement of Discrimination in America, edited by M. Fix and R. J. Struyk, 1-67. Washington, DC: The Urban Institute Press.

Fix, Michael, and Margery Austin Turner. 1999. "Measuring Racial and Ethnic Discrimination in America." In A National Report Card on Discrimination in America: The Role of Testing, edited by M. Fix and M. A. Turner, 7-26. Washington, D.C.: The Urban Institute.

Friedman, Samantha. 2015. "Commentary: Housing Discrimination Research in the $21^{\text {st }}$ Century.” Cityscape, 17(3):143-50.

Friedman, Samantha, Gregory D. Squires, and Chris Galvan. 2010. "Cybersegregation in Boston and Dallas: Is Neil a More Desirable Tenant than Tyrone or Jorge?” Available online at http://mumford.albany.edu/mumford/cybersegregation/friedmansquiresgalvan.May2010. pdf

Fry, Eileen. 1986. An Equal Chance for Disabled People? A Study of Discrimination in Employment. London: The Spastics Society, Campaigns and Parliamentary Department.

Furst, R. Terry, and Douglas N. Evans. 2016. "Renting Apartments to Felons: Variations in Real Estate Agent Decisions due to Stigma.” Deviant Behavior, 38(6):698-708.

Gaddis, S. Michael. 2015. "Discrimination in the Credential Society: An Audit Study of Race and College Selectivity in the Labor Market.” Social Forces, 93(4):1451-79.

Gaddis, S. Michael. 2017a. "Racial/Ethnic Perceptions from Hispanic Names: Selecting Names to Test for Discrimination.” Available at SSRN: https://ssrn.com/abstract=2975829

Gaddis, S. Michael. 2017b. "Assessing Immigrant Generational Status from Names: Scientific Evidence for Experiments.” Available at SSRN: https://ssrn.com/abstract=3022217

Gaddis, S. Michael. 2017c. “Auditing Audit Studies: The Effects of Name Perception and Selection on Social Science Measurement of Racial Discrimination.” Available at SSRN: https://ssrn.com/abstract=3022207

Gaddis, S. Michael. 2017d. "A Field Experiment on Associate Degrees and Certificates: Statistical Discrimination, Stigma, Signal Boost, and Signal Saturation.” Available at SSRN: https://ssrn.com/abstract=3022203

Gaddis, S. Michael. Forthcoming. "How Black are Lakisha and Jamal? Racial Perceptions from Names Used in Correspondence Audit Studies.” Sociological Science.

Gaddis, S. Michael, and Raj Ghoshal. 2015. "Arab American Housing Discrimination, Ethnic Competition, and the Contact Hypothesis." The ANNALS of the American Academy of 
Political and Social Science, 660(1):282-99.

Gaddis, S. Michael, and Raj Ghoshal. 2017. "Why do Millennials Engage in Racial Discrimination? (When They Say They Won't)." Available at SSRN: https://ssrn.com/abstract=3022208

Galarza, Francisco B., and Gustavo Yamada. 2014. "Labor Market Discrimination in Lima, Peru: Evidence from a Field Experiment.” World Development, 58:83-94.

Galarza, Francisco B., and Gustavo Yamada. 2017. "Triple Penalty in Employment Access: The Role of Beauty, Race, and Sex.” Journal of Applied Economics, 20(1):29-47.

Galgano, Sarah Wittig. 2009. "Barriers to Reintegration: An Audit Study of the Impact of Race and Offender Status on Employment Opportunities for Women." Social Thought \& Research, 30:21-37.

Galster, George. 1990a. "Racial Steering in Urban Housing Markets: A Review of the Audit Evidence.” Review of Black Political Economy, 18(3):105-29.

Galster, George. 1990b. "Racial Discrimination in Housing Markets in the 1980s: A Review of the Audit Evidence.” Journal of Planning Education and Research, 9(3):165-75.

Galster, George, and Peter Constantine. 1991. "Discrimination against Female-Headed Households in Rental Housing: Theory and Exploratory Evidence.” Review of Social Economy, 49(1):76-100.

Galster, George, and Erin Godfrey. 2005. "By Words and Deeds: Racial Steering by Real Estate Agents in the U.S. in 2000.” Journal of the American Planning Association, 71(3):251-68.

Galster, George, Heather MacDonald, and Jacqueline Nelson. Forthcoming. "What Explains the Differential Treatment of Renters Based on Ethnicity? New Evidence from Sydney." Urban Affairs Review. DOI: 10.1177/1078087416679735

Ge, Yanbo, Christopher R. Knittel, Don MacKenzie, and Stephen Zoepf. 2016. "Racial and Gender Discrimination in Transportation Network Companies.” Available at NBER: http://www.nber.org/papers/w22776

Gell-Redman, Micah, Neil Visalvanich, Charles Crabtree, and Christopher J. Fariss. 2017. "It’s All About Race: How State Legislators Respond to Immigrant Constituents.” Available at SSRN: https://ssrn.com/abstract=2999173

Gerber, Alan S., and Donald P. Green. 2012. Field Experiments: Design, Analysis, and Interpretation. New York, NY: W.W. Norton. 
Ghoshal, Raj, and S. Michael Gaddis. 2015. "Finding a Roommate on Craigslist: Racial Discrimination and Residential Segregation.” Available at SSRN: https://ssrn.com/abstract=2605853

Giulietti, Corrado, Mirco Tonin, and Michael Vlassopoulos. 2015. "Racial Discrimination in Local Public Services: A Field Experiment in the U.S.” Available at SSRN: https://ssrn.com/abstract=2681054

Gneezy, Uri, and John List. 2004. “Are the Disabled Discriminated against in Product Markets? Evidence from Field Experiments.” American Economic Association Annual Meeting.

Gneezy, Uri, John List, and Michael K. Price. 2012. "Toward an Understanding of Why People Discriminate: Evidence from a Series of Natural Field Experiments.” Available at NBER: http://www.nber.org/papers/w17855

Goldberg, Andreas, Dora Mourinho, and Ursula Kulke. 1995. Labour Market Discrimination against Foreign Workers in Germany. Geneva: International Labour Office, Employment Department.

Graham, Pauline, Antoinette Jordan, and Brian Lamb. 1990. An Equal Chance or No Chance? A Study of Discrimination against Disabled People in the Labour Market. London: The Spastics Society.

Gras, M., F. Bovenkerk, K. Gorter, P. Kruiswijk, and D. Ramsoedh. 1996. “Een schijn van kans: Twee empirische onderzoekingen naar discriminatie op grond van handicap en etnische afkomst.” Netherlands: Gouda Quint.

Guryan, Jonathan, and Kerwin Kofi Charles. 2013. “Taste-Based or Statistical Discrimination: The Economics of Discrimination Returns to Its Roots.” The Economics Journal, 123:F417-32.

Hakken, Jon. 1979. Discrimination against Chicanos in the Dallas Rental Housing Market: An Experimental Extension of the Housing Market Practices Survey. Washington, D.C.: U.S. Department of Housing and Urban Development.

Hansen, J. L., and Franklin J. James. 1987. "Housing Discrimination in Small Cities and Nonmetropolitan Areas.” In Divided Neighborhoods: Changing Patterns of Racial Segregation, edited by G. A. Tobin, 181-207. Thousand Oaks, CA: Sage Publications.

Hanson, Andrew, and Zackary Hawley. 2011. "Do Landlords Discriminate in the Rental Housing Market? Evidence from an Internet Field Experiment in US Cities.” Journal of Urban Economics, 70(2):99-114.

Hanson, Andrew, and Zackary Hawley. 2014. "Where Does Racial Discrimination Occur? An Experimental Analysis across Neighborhood and Housing Unit Characteristics.” Regional Science and Urban Economics, 44:94-106. 
Hanson, Andrew, Zackary Hawley, and Hal Martin. 2017. "Does Differential Treatment Translate to Differential Outcomes for Minority Borrowers? Evidence from Matching a Field Experiment to Loan-Level Data.” Available at SSRN:

https://ssrn.com/abstract=2945493

Hanson, Andrew, Zachary Hawley, Hal Martin, and Bo Liu. 2016. "Discrimination in Mortgage Lending: Evidence from a Correspondence Experiment.” Journal of Urban Economics, 92:48-65.

Hanson, Andrew, Zackary Hawley, and Aryn Taylor. 2011. "Subtle Discrimination in the Rental Housing Market: Evidence from E-mail Correspondence with Landlords." Journal of Housing Economics, 20(4):276-284.

Hanson, Andrew, and Michael Santas. 2014. "Field Experiment Tests for Discrimination against Hispanics in the U.S. Rental Housing Market.” Southern Economic Journal, 81(1):135-167.

Heckman, James J. 1998. “Detecting Discrimination.” Journal of Economic Perspectives, 12(2):101-16.

Heckman, James J., and Peter Siegelman. 1993. “The Urban Institute Audit Studies: Their Methods and Findings.” In Clear and Convincing Evidence: Measurement of Discrimination in America, edited by M. Fix and R. J. Struyk, 187-258. Washington, DC: The Urban Institute Press.

Hemker, Johannes, and Anselm Rink. Forthcoming. "Multiple Dimensions of Bureaucratic Discrimination: Evidence from German Welfare Offices.” American Journal of Political Science. DOI: 10.1111/ajps.12312

Henry, Frances, and Effie Ginzberg. 1985. Who Gets the Work? A Test of Racial Discrimination in Employment. Toronto: The Urban Alliance on Race Relations and the Social Planning Council of Metropolitan Toronto.

Heylen, Kristof, and Katleen Van den Broeck. 2016. "Discrimination and Selection in the Belgian Private Rental Market.” Housing Studies, 31(2):223-36.

Hipes, Crosby, Jeffrey Lucas, Jo C. Phelan, and Richard C. White. 2016. "The Stigma of Mental Illness in the Labor Market.” Social Science Research, 56:16-25.

Hitt, M. A., W. G. Zikmund, and B. A. Pickens. 1982. "Discrimination in Industrial Employment: An Investigation of Race and Sex Bias among Professionals.” Work and Occupations, 9(2):217-31.

Hjarnø, Jan, and Torben Jensen. 2008. "Discrimination in Employment against Immigrants in Denmark: A Situation Testing Survey.” Geneva: International Labour Office. 
Hogan, Bernie, and Brent Berry. 2011. "Racial and Ethnic Biases in Rental Housing: An Audit Study of Online Apartment Listings.” City \& Community, 10(4):351-72.

Hubbock, Jim, and Simon Carter. 1980. Half a Chance? A Report on Job Discrimination against Young Blacks in Nottingham. London: Commission for Racial Equality.

Hughes, D. Alex, Micah Gell-Redman, Charles Crabtree, Natarajan Krishnaswami, Diana Rodenberger, and Guillermo Monge. 2017. "Who Gets to Vote? New Evidence of Discrimination among Local Election Officials.” Working paper available online at http://cess.nyu.edu/wp-content/uploads/2017/02/Who-Gets-to-Vote.pdf

Jackson, Michelle. 2009. “Disadvantaged through Discrimination? The Role of Employers in Social Stratification.” The British Journal of Sociology, 60(4):669-92.

Jackson, Michelle, and D. R. Cox. 2013. "The Principles of Experimental Design and Their Application in Sociology.” Annual Review of Sociology, 39:27-49.

Jacquemet, Nicolas, and Constantine Yannelis. 2012. "Indiscriminate Discrimination: A Correspondence Test for Ethnic Homophily in the Chicago Labor Market.” Labour Economics, 19(6):824-32.

James, Franklin, and Steven DelCastillo. 1992. "Measuring Job Discrimination: Hopeful Evidence from Recent Audits.” Harvard Journal of African American Public Policy, 1:33-53.

James, Franklin, Betty McCummings, and Eileen Tynan. 1984. Minorities in the Sunbelt. New Burnswick, NJ: Rutgers Center for Urban Policy Research.

Janusz, Andrew, and Nazita Lajevardi. 2016. “The Political Marginalization of Latinos: Evidence from Three Field Experiments.” Available at SSRN: https://ssrn.com/abstract=2799043

Johnson, Daniel A., Richard J. Porter, and Patricia L. Mateljan. 1971. "Racial Discrimination in Apartment Rentals.” Journal of Applied Social Psychology, 1(4): 364-77.

Johnson, Emily, and Joanna Lahey. 2011. “The Resume Characteristics Determining Job Interviews for Middle-Aged Women Seeking Entry-Level Employment.” Journal of Career Development, 38(4):310-330.

Jolson, Marvin A. 1974. “Employment Barrier in Marketing.” Journal of Marketing, 38(2):67-9.

Jowell, Roger, and Patricia Prescott-Clarke. 1970. "Racial Discrimination and White-Collar Workers in Britain.” Race, 11(4):397-417. 
Kaas, Leo, and Christian Manger. 2012. "Ethnic Discrimination in Germany's Labour Market: a Field Experiment.” German Economic Review, 13(1):1-20.

Kang, Sonia K., Katherine A. DeCelles, András Tilcsik, and Sora Jun. 2016. “Whitened Resumes: Race and Self-Presentation in the Labor Market.” Administrative Science Quarterly, 61(3):469-502.

Kirschenman, Joleen, and Kathryn M. Neckerman. 1991. “'We'd Love to Hire Them, But...': The Meaning of Race for Employers.” In The Urban Underclass, edited by C. Jencks and P. E. Peterson, 203-32. Washington, D.C.: The Brookings Institution.

Kleykamp, Meredith. 2009. “A Great Place to Start? The Effect of Prior Military Service on Hiring.” Armed Forces \& Society, 35(2):266-85.

Kovar, Leopold J. 1974. Auditing Real Estate Practices: A Manual. Philadelphia, PA: National Neighbors.

Kroft, Kory, Fabian Lange, and Matthew J. Notowidigdo. 2013. "Duration Dependence and Labor Market Conditions: Evidence from a Field Experiment.” The Quarterly Journal of Economics, 128(3):1123-67.

Kugelmass, Heather. 2016. “'Sorry, I’m Not Accepting New Patients': An Audit Study of Access to Mental Health Care.” Journal of Health and Social Behavior, 57(2):168-83.

Lahey, Joanna N. 2008. “Age, Women, and Hiring: An Experimental Study.” Journal of Human Resources, 43(1):30-56.

Lahey, Joanna N., and Ryan A. Beasley. 2009. “Computerizing Audit Studies.” Journal of Economic Behavior \& Organization, 70(3):508-14.

Lahey, Joanna N., and Ryan A. Beasley. 2017. “Technical Aspects of Correspondence Studies.” In Audit Studies: Behind the Scenes with Theory, Method, and Nuance, edited by S. M. Gaddis, pXX-pXX. Springer.

Lanning, Jonathan A. 2013. “Opportunities Denied, Wages Diminished: Using Search Theory to Translate Audit-Pair Study Findings into Wage Differentials.” The B.E. Journal of Economic Analysis \& Policy, 13(2):921-58.

Lauster, Nathanael, and Adam Easterbrook. 2011. "No Room for New Families? A Field Experiment Measuring Rental Discrimination against Same-Sex Couples and Single Parents.” Social Problems, 58(3):389-409.

Leadership Council for Metropolitan Open Communities. 1975. Investigation and Auditing in Fair Housing Cases. Chicago, IL: Leadership Council for Metropolitan Open Communities. 
Lee, Hwok-Aun, and Muhammed Abdul Khalid. 2016. "Discrimination of High Degrees: Race and Graduate Hiring in Malaysia.” Journal of the Asia Pacific Economy, 21(1):53-76.

Levinson, Richard M. 1975. "Sex Discrimination and Employment Practices: An Experiment with Unconventional Job Inquiries.” Social Problems, 22(4):533-43.

List, John A. 2004. "The Nature and Extent of Discrimination in the Marketplace: Evidence from the Field.” The Quarterly Journal of Economics, 119(1):49-89.

Lodder, LeeAnn, Scott McFarland, and Diana White. 2003. Racial Preference and Suburban Employment Opportunities. Chicago, IL: Legal Assistance Foundation of Chicago.

Lucas, Samuel Roundfield. 2008. Theorizing Discrimination in an Era of Contested Prejudice: Discrimination in the United States, Volume 1. Philadelphia, PA: Temple University Press.

MacDonald, Heather, George Galster, and Rae Dufty-Jones. Forthcoming. "The Geography of Rental Housing Discrimination, Segregation, and Social Exclusion: New Evidence from Sydney.” Journal of Urban Affairs. DOI: 10.1080/07352166.2017.1324247

Massey, Douglas S., and Garvey Lundy. 2001. "Use of Black English and Racial Discrimination in Urban Housing Markets: New Methods and Findings.” Urban Affairs Review, 36(4):452-69.

Maurer-Fazio, Margaret. 2012. “Ethnic Discrimination in China's Internet Job Board Labor Market.” IZA Journal of Migration, 1(1):12.

Maurer-Fazio, Margaret, and Lei Lei. 2015. “'As Rare as a Panda': How Facial Attractiveness, Gender, and Occupation Affect Interview Callbacks at Chinese Firms.” International Journal of Manpower, 36(1):68-85.

Mazziotta, Agostino, Michael Zerr, and Anette Rohmann. 2015. "The Effects of Multiple Stigmas on Discrimination in the German Housing Market.” Social Psychology, 46(6):325-34.

McClendon, Gwyneth H. 2016. "Race and Responsiveness: An Experiment with South African Politicians.” Journal of Experimental Political Science, 3(1):60-74.

McGinnity, Frances, and Peter D. Lunn. 2011. "Measuring Discrimination Facing Ethnic Minority Job Applicants: An Irish Experiment.” Work, Employment and Society, 25(4):693-708.

McIntosh, Neil, and David J. Smith. 1974. The Extent of Racial Discrimination. London, U.K.: PEP, The Social Science Institute. 
McIntyre, Shelby, Dennis J. Moberg, and Barry Z. Posner. 1980. "Preferential Treatment in Preselection Decisions According to Sex and Race.” Academy of Management Journal, 23(4):738-49.

Mendez, Matthew S., and Christian R. Grose. 2014. "Doubling Down: Inequality in Responsiveness and the Policy Preferences of Elected Officials.” Available at SSRN: https://ssrn.com/abstract=2422596

Michelitch, Kristin. 2015. "Does Electoral Competition Exacerbate Interethnic or Interpartisan Economic Discrimination? Evidence from a Field Experiment in Market Price Bargaining.” American Political Science Review, 109(1):43-61.

Midtbøen, Arnfinn H. 2014. "The Invisible Second Generation? Statistical Discrimination and Immigrant Stereotypes in Employment Processes in Norway." Journal of Ethnic and Migration Studies, 40(10):1657-75.

Midtbøen, Arnfinn H. 2015. "The Context of Employment Discrimination: Interpreting the Findings of a Field Experiment.” The British Journal of Sociology, 66(1):193-214.

Midtbøen, Arnfinn H. 2016. "Discrimination of the Second Generation: Evidence from a Field Experiment in Norway.” Journal of International Migration and Integration, 17(1):253-72.

Milkman, Katherine L., Modupe Akinola, and Dolly Chugh. 2012. "Temporal Distance and Discrimination: An Audit Study in Academia.” Psychological Science, 23(7):710-7.

Milkman, Katherine L., Modupe Akinola, and Dolly Chugh. 2015. "What Happens Before? A Field Experiment Exploring How Pay and Representation Differentially Shape Bias on the Pathway into Organizations.” Journal of Applied Psychology, 100(6):1678-1712.

Mincy, Ronald B. 1993. "The Urban Institute Audit Studies: Their Research and Policy Context." In Clear and Convincing Evidence: Measurement of Discrimination in America, edited by M. Fix and R. J. Struyk, 165-86. Washington, DC: The Urban Institute Press.

Mishel, Emma. 2016. "Discrimination Against Queer Women in the U.S. Workforce: A Resume Audit Study.” Socius: Sociological Research for a Dynamic World. DOI: 10.1177/2378023115621316

Murphy, Joellyn Kapp. 1972. Audit Handbook: Procedures for Determining the Extent of Racial Discrimination in Apartment Rentals. Palo Alto, CA: Mid-peninsula Citizens for Fair Housing.

Namingit, Sheryll, William Blankenau, and Benjamin Shwab. 2017. "Sick and Tell: A Field Experiment Analyzing the Effects of an Illness-Related Employment Gap on the Callback Rate.” Working paper available at: 
https://economics.ku.edu/sites/economics.ku.edu/files/files/Seminar/papers1617/ March31.pdf

Neumark, David. 2012. "Detecting Discrimination in Audit and Correspondence Studies.” The Journal of Human Resources, 47(4):1128-57.

Neumark, David. Forthcoming. "Experimental Research on Labor Market Discrimination.” Journal of Economic Literature.

Neumark, David, Roy J. Bank, and Kyle D. Van Nort. 1996. "Sex Discrimination in Hiring in the Restaurant Industry: An Audit Study.” Quarterly Journal of Economics, 111(3):915-42.

Neumark, David, Ian Burn, and Patrick Button. 2015. "Is It Harder for Older Workers to Find Jobs? New and Improved Evidence from a Field Experiment.” Available at NBER: http://www.nber.org/papers/w21669

Neumark, David, Ian Burn, and Patrick Button. 2016. "Experimental Age Discrimination Evidence and the Heckman Critique." American Economic Review: Papers and Proceedings, 106(5):303-8.

Neumark, David, Ian Burn, Patrick Button, and Nanneh Chehras. 2017. "Do State Laws Protecting Older Workers from Discrimination Laws Reduce Age Discrimination in Hiring? Experimental (and Nonexperimental) Evidence.” Available at SSRN: https://ssrn.com/abstract=2900439

Neumark, David, and Judith Rich. 2016. "Do Field Experiments on Labor and Housing Markets Overstate Discrimination? A Re-Examination of the Evidence.” Available at NBER: http://www.nber.org/papers/w22278

Newburger, Harriet. 1984. Recent Evidence on Discrimination in Housing. US Department of Housing and Urban Development, Office of Policy Development and Research.

Newman, Jerry M. 1978. "Discrimination in Recruitment: An Empirical Analysis.” Industrial and Labor Relations Review, 32(1):15-23.

Nunes, Ana P., and Brad Seligman. 1999. "Treatment of Caucasian and African-American Applicants by San Francisco Bay Area Employment Agencies: Results of a Study Utilizing 'Testers'.” The Testing Project of the Impact Fund. San Francisco, CA: The Impact Fund.

Nunes, Ana P., and Brad Seligman. 2000. "A Study of the Treatment of Female and Male Applicants by San Francisco Bay Area Auto Service Shops.” The Testing Project of the Impact Fund. San Francisco, CA: The Impact Fund. 
Nunley, John M., Mark F. Owens, and R. Stephen Howard. 2011. "The Effects of Information and Competition on Racial Discrimination: Evidence from a Field Experiment.” Journal of Economic Behavior \& Organization, 80(3):670-679.

Nunley, John M., Adam Pugh, Nicholas Romero, and R. Alan Seals Jr. 2015. “Racial Discrimination in the Labor Market for Recent College Graduates: Evidence from a Field Experiment.” The B.E. Journal of Economic Analysis \& Policy, 15(3):1093-1125.

Nunley, John M., Adam Pugh, Nicholas Romero, and R. Alan Seals Jr. 2016. "College Major, Internship Experience, and Employment Opportunities: Estimates from a Resume Audit." Labour Economics, 38:37-46.

Nunley, John M., Adam Pugh, Nicholas Romero, and R. Alan Seals Jr. 2017. “The Effects of Unemployment and Underemployment on Employment Opportunities: Results from a Correspondence Audit of the Labor Market for College Graduates.” ILR Review, 70(3):642-669.

Oh, Sun Jung, and John Yinger. 2015. "What Have We Learned from Paired Testing Housing Markets?” Cityscape: A Journal of Policy Development Research, 17(3):15-59.

Ondrich, Jan, Alex Stricker, and John Yinger. 1998. "Do Real Estate Brokers Choose to Discriminate? Evidence from the 1989 Housing Discrimination Study.” Southern Economic Journal, 64(4):880-901.

Oreopoulos, Philip. 2011. "Why do Skilled Immigrants Struggle in the Labor Market? A Field Experiment with Thirteen Thousand Resumes.” American Economic Journal: Economic Policy, 3(4):148-171.

Oreopoulos, Philip, and Diane Dechief. 2012. "Why Do Some Employers Prefer to Interview Matthew, but Not Samir? New Evidence from Toronto, Montreal, and Vancouver.” Available at SSRN: https://ssrn.com/abstract=2018047

Page, Marianne. 1995. "Racial and Ethnic Discrimination in Urban Housing Markets: Evidence from a Recent Audit Study.” Journal of Urban Economics, 38(2):183-206.

Pager, Devah. 2003. “The Mark of a Criminal Record.” American Journal of Sociology, 108(5):937-75.

Pager, Devah. 2007a. "The Use of Field Experiments for Studies of Employment Discrimination: Contributions, Critiques, and Directions for the Future.” The ANNALS of the American Academy of Political and Social Science, 609:104-33.

Pager, Devah. 2007b. Marked: Race, Crime, and Finding Work in an Era of Mass Incarceration. Chicago, IL: The University of Chicago Press. 
Pager, Devah. 2016. “Are Firms that Discriminate More Likely to Go Out of Business?” Sociological Science, 3:849-59.

Pager, Devah, and Lincoln Quillian. 2005. "Walking the Talk? What Employers Say Versus What They Do.” American Sociological Review, 70(3):355-80.

Pager, Devah, and Hana Shepherd. 2008. "The Sociology of Discrimination: Racial Discrimination in Employment, Housing, Credit, and Consumer Markets.” Annual Review of Sociology, 34:181-209.

Pager, Devah, Bruce Western, and Bart Bonikowski. 2009. "Discrimination in a Low-Wage Labor Market: A Field Experiment.” American Sociological Review, 74(5)777-99.

Pager, Devah, Bruce Western, and Naomi Sugie. 2009. "Sequencing Disadvantage: Barriers to Employment Facing Young Black and White Men with Criminal Records." The ANNALS of the American Academy of Political and Social Science, 623:195-213.

Patacchini, Eleonora, Giuseppe Ragusa, and Yves Zenou. 2015. "Unexplored Dimensions of Discrimination in Europe: Homosexuality and Physical Appearance.” Journal of Population Economics, 28(4):1045-1073.

Pearce, Diana M. 1979. "Gatekeepers and Homeseekers: Institutional Patterns in Racial Steering.” Social Problems, 26(3):325-42.

Pedulla, David S. 2016. "Penalized or Protected? Gender and the Consequences of Nonstandard and Mismatched Employment Histories.” American Sociological Review, 81(2):262-289.

Pedulla, David S. 2017. "Emerging Frontiers in Audit Study Research: Mechanisms, Variation, and Representativeness.” In Audit Studies: Behind the Scenes with Theory, Method, and Nuance, edited by S. M. Gaddis, pXX-pXX. Springer.

Petit, Pascale. 2007. "The Effects of Age and Family Constraints on Gender Hiring Discrimination: A Field Experiment in the French Financial Sector.” Labour Economics, 14(3):371-91.

Phillips, David C. 2016a. "Do Low-Wage Employers Discriminate Against Applicants With Long Commutes? Evidence from a Correspondence Experiment.” Working paper. Available at: https://sites.google.com/site/davidcphillipseconomics/research

Phillips, David C. 2016b. "Do Comparisons of Fictional Applicants Measure Discrimination When Search Externalities Are Present? Evidence from Existing Experiments.” Working paper. Available at: https://sites.google.com/site/davidcphillipseconomics/research

Phillips, David C. 2017. "Landlords Avoid Tenants Who Pay with Vouchers.” Economics Letters, 151:48-52. 
Pierné, Guillaume. 2013. "Hiring Discrimination Based on National Origin and Religious Closeness: Results from a Field Experiment in the Paris Area.” IZA Journal of Labor Economics, 2(4):1-15.

Pitingolo, Rob, and Stephen L. Ross. 2015. "Housing Discrimination among Available Housing Units in 2012: Do Paired-Testing Studies Understand Housing Discrimination?” Cityscape, 17(3):61-85.

Porter, Nathaniel D., Ashton M. Verdery, and S. Michael Gaddis. 2017. "Enhancing Big Data in the Social Sciences with Crowdsourcing: Data Augmentation Practices, Techniques, and Opportunities.” Available at SSRN: https://ssrn.com/abstract=2844155

Purnell, Brian. 2013. Fighting Jim Crow in the County of Kings: The Congress of Racial Equality in Brooklyn. Lexington, KY: University Press of Kentucky.

Purnell, Thomas, William Idsardi, and John Baugh. 1999. "Perceptual and Phonetic Experiments on American English Dialect Identification.” Journal of Language and Social Psychology, 18(1):10-30.

Quillian, Lincoln. 2006. “New Approaches to Understanding Racial Prejudice and Discrimination.” Annual Review of Sociology, 32:299-328.

Quillian, Lincoln, Devah Pager, Ole Hexel, and Arnfinn Midtbøen. Forthcoming. “The Persistence of Racial Discrimination: A Meta-Analysis of Field Experiments in Hiring over Time.” Proceedings of the National Academy of Sciences.

Ravaud, Jean-François, Béatrice Madiot, and Isabelle Ville. 1992. “Discrimination towards Disabled People Seeking Employment.” Social Science \& Medicine, 35(8):951-8.

Riach, Peter A. 2015. “A Field Experiment Investigating Age Discrimination in Four European Labour Markets.” International Review of Applied Economics, 29(5):608-19.

Riach, Peter A., and Judith Rich. 1987. “Testing for Sexual Discrimination in the Labour Market.” Australian Economic Papers, 26(49):165-78.

Riach, Peter A., and Judith Rich. 1991. "Testing for Racial Discrimination in the Labour Market.” Cambridge Journal of Economics, 15(3):239-56.

Riach, Peter A., and Judith Rich. 2002. "Field Experiments of Discrimination in the Market Place” The Economic Journal, 112:F480-F518.

Riach, Peter A., and Judith Rich. 2006a. “An Experimental Investigation of Sexual Discrimination in Hiring in the English Labor Market.” The B.E. Journal of Economic Analysis \& Policy, 6(2): Article 1. 
Riach, Peter A., and Judith Rich. 2006b. "An Experimental Investigation of Age Discrimination in the French Labour Market.” Available at SSRN: https://ssrn.com/abstract=956389

Riach, Peter A., and Judith Rich. 2007. "An Experimental Investigation of Age Discrimination in the Spanish Labour Market.” Available at SSRN: https://ssrn.com/abstract=970498

Riach, Peter A., and Judith Rich. 2010. "An Experimental Investigation of Age Discrimination in the English Labor Market.” Annals of Economics and Statistics, 99/100:169-85.

Rich, Judith. 2014. "What Do Field Experiments of Discrimination in Markets Tells Us? A Meta-Analysis of Studies Conducted Since 2000.” Available at SSRN: https://ssrn.com/abstract=2517887

Ridley, Stanley, James A. Bayton, and Janice Hamilton Outtz. 1989. "Taxi Service in the District of Columbia: Is it Influenced by Patron's Race and Destination?” Washington, DC Lawyer's Committee for Civil Rights Under the Law.

Rivera, Lauren A., and András Tilcsik. 2016. "Class Advantage, Commitment Penalty: The Gendered Effect of Social Class Signals in an Elite Labor Market.” American Sociological Review, 81(6):1097-1131.

Romei, Andrea, and Salvatore Ruggieri. 2013. "A Multidisciplinary Survey on Discrimination Analysis.” The Knowledge Engineering Review, 29(5):582-638.

Rooth, Dan-Olof. 2009. "Obesity, Attractiveness, and Differential Treatment in Hiring: A Field Experiment.” Journal of Human Resources, 44(3):710-35.

Rooth, Dan-Olof. 2010. “Automatic Associations and Discrimination in Hiring: Real World Evidence.” Labour Economics, 17(3):523-34.

Ross, Stephen L., and Margery Austin Turner. 2005. "Housing Discrimination in Metropolitan America: Explaining Changes between 1989 and 2000.” Social Problems, 52(2):152-80.

Rowland, Stanley, Jr. 1956. "Race Bias Easing in Churches Here: Many Congregations Employ 'Open Door’ Policy—Housing Discrimination Persists,” New York Times, February 12:1.

Roychoudhury, Canopy, and Allen C. Goodman. 1992. "An Ordered Probit Model for Estimating Racial Discrimination through Fair Housing Audits.” Journal of Housing Economics, 2(4):358-73.

Roychoudhury, Canopy, and Allen C. Goodman. 1996. "Evidence of Racial Discrimination in Different Dimensions of Owner-Occupied Housing Search.” Real Estate Economics, 24(2):161-78.

Ruffle, Bradley J., and Ze'ev Shtudiner. 2015. “Are Good-Looking People More Employable?” Management Science, 61(8):1760-1776. 
Saltman, Juliet. 1975. “Implementing Open Housing Laws through Social Action.” Journal of Applied Behavioral Science, 11(1): 39-61.

Sharma, Rajiv, Arnab Mitra, and Miron Stano. 2015. "Insurance, Race/Ethnicity, and Sex in the Search for a New Physician.” Economics Letters, 137:150-3.

Shin, Ricahrd Q., Lance C. Smith, Jamie C. Welch, and Ijeoma Ezeofor. 2016. "Is Allison More Likely than Lakisha to Receive a Callback from Counseling Professionals? A Racism Audit Study.” The Counseling Psychologist, 44(8):1187-1211.

Siddique, Zahra. 2011. “Evidence on Caste Based Discrimination.” Labour Economics, 18(S1):S146-S159.

Smeesters, B., and A. Nayer. 1998. "La Discrimination a L'acces a L'emploi en Raison de L'origine Etrangere: Le Cas de le Belgique.” Geneva: International Labour Office, Conditions of Work Branch.

Smith, David J. 2015. “W. W. Daniel Obituary.” The Guardian, November 10. Available online at: https://www.theguardian.com/education/2015/nov/10/ww-daniel

Smith, Robin, and Michelle DeLair. 1999. "New Evidence from Lender Testing: Discrimination at the Pre-Application Stage.” In Mortgage Lending Discrimination: A Review of Existing Evidence, edited by M. A. Turner and F. Skidmore, 23-41. Washington, DC: Urban Institute Press.

Smith, Shanna L. and Cathy Cloud. 1996. “The Role of Private, Nonprofit Fair Housing Enforcement Organizations in Lending Testing.” In Mortgage Lending, Racial Discrimination, and Federal Policy, edited by J. Goering and R. Wienk, 589-610. Washington, D.C.: Urban Institute Press.

Stone, Anna, and Toby Wright. 2013. “When Your Face Doesn’t Fit: Employment Discrimination against People with Facial Disfigurements.” Journal of Applied Social Psychology, 43(3):515-26.

Thanasombat, Siri, and John Trasviña. 2005. "Screening Names Instead of Qualifications: Testing with Emailed Resumes Reveals Racial Preferences.” AAPI Nexus: Policy, Practice, and Community, 3(2):105-15.

Tilcsik, András. 2011. "Price and Prejudice: Employment Discrimination against Openly Gay Men in the United States.” American Journal of Sociology, 117(2):586-626.

Tunstall, Rebecca, Anne Green, Ruth Lupton, Simon Watmough, Katie Bates. 2014. “Does Poor Neighborhood Reputation Create a Neighbourhood Effect on Employment? The Results of a Field Experiment in the UK.” Urban Studies, 51(4):763-80. 
Turner, Margery A., Michael Fix, and Raymond J. Struyk. 1991. Opportunities Denied, Opportunities Diminished: Racial Discrimination in Hiring. Washington, D.C.: The Urban Institute Press.

Turner, Margery A., Carla Herbig, Deborah Kaye, Julie Fenderson, and Diane Levy. 2005. Discrimination against Persons with Disabilities: Barriers at Every Step. Washington, DC: The Urban Institute Press.

Turner, Margery A., and Judson James. 2015. "Discrimination as an Object of Measurement.” Cityscape: A Journal of Policy Development Research, 17(3):3-14.

Turner, Margery A., Maris Mikelsons, and John Edwards. 1990. Analysis of Steering in the Housing Discrimination Study. Washington, DC: U.S. Department of Housing and Urban Development, Office of Policy Development and Research.

Turner, Margery A., and Stephen L. Ross. 2003a. Discrimination in Metropolitan Housing Markets: Phase 2 - Asians and Pacific Islanders Final Report. Washington, DC: The Urban Institute Press.

Turner, Margery A., and Stephen L. Ross. 2003b. Discrimination in Metropolitan Housing Markets: Phase 3 - Native Americans. Washington, DC: The Urban Institute Press.

Turner, Margery A., Stephen L. Ross, George C. Galster, and John Yinger. 2002. Discrimination in Metropolitan Housing Markets: National Results From Phase 1 HDS 2000. Washington, DC: U.S. Department of Housing and Urban Development, Office of Policy Development and Research.

Turner, Margery A., Rob Santos, Diane K. Levy, Doug Wissoker, Claudia Aranda, and Rob Pitingolo. 2013. Housing Discrimination Against Racial and Ethnic Minorities 2012. Washington, DC: U.S. Department of Housing and Urban Development, Office of Policy Development and Research.

Turner, Margery A., Raymond J. Struyk, and John Yinger. 1991. Housing Discrimination Study: Synthesis. Washington, D.C.: U.S. Department of Housing and Urban Development.

Uggen, Christopher, Mike Vuolo, Sarah Lageson, Ebony Ruhland, and Hilary K. Whitham. 2014. "The Edge of Stigma: An Experimental Audit of the Effects of Low-Level Criminal Records on Employment.” Criminology, 52(4):627-654.

Van der Bracht, Koen, Ad Coenen, and Bart Van de Putte. 2015. “The Not-in-My-Property Syndrome: The Occurrence of Ethnic Discrimination in the Rental Housing Market in Belgium.” Journal of Ethnic and Migration Studies, 41(1):158-75.

Verhaeghe, Pieter-Paul, Koen Van der Bracht, and Bart Van de Putte. 2016. "Discrimination of Tenants with a Visual Impairment on the Housing Market: Empirical Evidence form Correspondence Tests." Disability and Health Journal, 9(2):234-8. 
Verhaest, Dieter, Elene Bogaert, Jeroen Dereymaeker, Laura Mestdagh, and Stijn Baert. Forthcoming. "Do Employers Prefer Overqualified Graduates? A Field Experiment.” Industrial Relations.

Vuolo, Mike, Christopher Uggen, and Sarah Lageson. 2016. "Statistical Power in Experimental Audit Studies: Cautions and Calculations for Matched Tests with Nominal Outcomes.” Sociological Methods \& Research, 45(2):260-303.

Vuolo, Mike, Christopher Uggen, and Sarah Lageson. 2017a. "Race, Recession, and Social Closure in the Low-Wage Labor Market: Experimental and Observational Evidence.” Research in the Sociology of Work, 30:141-83.

Vuolo, Mike, Christopher Uggen, and Sarah Lageson. 2017b. “To Match or Not to Match? Statistical and Substantive Considerations in Audit Design and Analysis.” In Audit Studies: Behind the Scenes with Theory, Method, and Nuance, edited by S. M. Gaddis, pXX-pXX. Springer.

Wallace, Michael, Bradley R. E. Wright, and Allen Hyde. 2014. "Religious Affiliation and Hiring Discrimination in the American South: A Field Experiment.” Social Currents, 1(2):189-207.

Wallace, Michael, Bradley R. E. Wright, Christine Zozula, Stacy Missari, Christopher M. Donnelly, and Annie Scola Wisnesky. 2012. "A New Approach for Studying Stratification and Religion: Early Results from a National Internet-Based Field Experiment Study of U.S. Churches.” Research in the Sociology of Work, 23:369-397.

Weichselbaumer, Doris. 2000. "Is it Sex or Personality? The Impact of Sex-Stereotypes on Discrimination in Applicant Selection. Univ. of Linz Economics Working Paper No. 0021. Available at SSRN: https://ssrn.com/abstract=251249

Weichselbaumer, Doris. 2003. “Sexual Orientation Discrimination in Hiring.” Labour Economics, 10(6):629-42.

Weichselbaumer, Doris. 2015. "Testing for Discrimination against Lesbians of Different Marital Status: A Field Experiment.” Industrial Relations: A Journal of Economy and Society, 54(1):131-161.

Weichselbaumer, Doris. 2016. "Discrimination Against Female Migrants Wearing Headscarves.” Available at SSRN: https://ssrn.com/abstract=2842960

Weichselbaumer, Doris. 2017. "Discrimination against Migrant Job Applicants in Austria: An Experimental Study.” German Economic Review, 18(2):237-265.

White, Ariel R., Noah L. Nathan, and Julie K. Faller. 2015. "What Do I Need to Vote? Bureaucratic Discretion and Discrimination by Local Election Officials.” American 
Political Science Review, 109(1):129-42.

Widner, Daniel, and Stephen Chicoine. 2011. "It's All in the Name: Employment Discrimination Against Arab Americans.” Sociological Forum, 26(4):806-23.

Wienk, Ronald E., Clifford E. Reid, John C. Simonson, and Frederick J. Eggers. 1979. Measuring Racial Discrimination in American Housing Markets: The Housing Market Practices Survey. Washington, D.C.: Department of Housing and Urban Development, Office of Policy Development and Research.

Wissoker, Douglas A., Wendy Zimmermann, and George Galster. 1998. Testing for Discrimination in Home Insurance. Washington, DC: The Urban Institute.

Wood, Martin, Jon Hales, Susan Purdon, Tanja Sejersen, and Oliver Hayllar. 2009. A Test for Racial Discrimination in Recruitment Practice in British Cities. Norwich: Department for Work and Pensions.

Wright, Bradley R. E., Michael Wallace, John Bailey, and Allen Hyde. 2013. "Religious Affiliation and Hiring Discrimination in New England: A Field Experiment." Research in Social Stratification and Mobility, 34:111-26.

Wright, Bradley R. E., Michael Wallace, Annie Scola Wisnesky, Christopher M. Donnelly, Stacy Missari, and Christine Zozula. 2015. "Religion, Race, and Discrimination: A Field Experiment of How American Churches Welcome Newcomers." Journal for the Scientific Study of Religion, 54(2):185-204.

Wysienska-Di Carlo, K., and Z. Karpinski. 2014. "Discrimination Facing Immigrant Job Applicants in Poland - Results of a Field Experiment.” Presented at the XVIII ISA World Congress of Sociology.

Yinger, John. 1986. "Measuring Racial Discrimination with Fair Housing Audits: Caught in the Act.” The American Economic Review, 76(5):881-93.

Yinger, John. 1991. "Acts of Discrimination: Evidence from the 1989 Housing Discrimination Study.” Journal of Housing Economics, 1:318-46.

Yinger, John. 1993. “Access Denied, Access Constrained: Results and Implications of the 1989 Housing Discrimination Study.” In Clear and Convincing Evidence: Measurement of Discrimination in America, edited by M. Fix and R. J. Struyk, 69-112. Washington, DC: The Urban Institute Press.

Yinger, John. 1995. Closed Doors, Opportunities Lost: The Continuing Costs of Housing Discrimination. New York, NY: Russell Sage Foundation. 
Zhao, Xian, and Monica Biernat. 2017. "Welcome to the U.S. but Change Your Name? Adopting Anglo Names and Discrimination.” Journal of Experimental Social Psychology, 70:59-68.

Zhou, Xiangyi, Jie Zhang, and Xuetao Song. 2013. “Gender Discrimination in Hiring: Evidence from 19,130 Resumes in China.” Available at SSRN: https://ssrn.com/abstract=2195840

Zschirnt, Eva, and Didier Ruedin. 2016. "Ethnic Discrimination in Hiring Decisions: A Meta-Analysis of Correspondence Tests 1990-2015.” Journal of Ethnic and Migration Studies, 42(7):1115-34.

Zussman, Asaf. 2013. "Ethnic Discrimination: Lessons from the Israeli Online Market for Used Cars.” The Economic Journal, 123:F433-F468. 